\title{
O Complexo Arqueológico de Palestina de Goiás/Brasil: uma avaliação dos conjuntos líticos mais antigos em contextualização macrorregional
}

\author{
Sibeli A. Viana ${ }^{\star}$, Marcos Paulo M. Ramos**, Julio Cezar Rubin de Rubin***, Maira Barberi****, Eric Boëda ${ }^{\star \star \star \star \star}$
}

Palavras-chave: Tecnologia

Lítica; Holoceno Médio;

Planalto Central Brasileiro.

Keywords: Lithic technology; Middle Holocene; Palestina de Goiás; the Brazilian Central Plateau.

\begin{abstract}
Resumo: Neste artigo, apresentamos resultados iniciais advindos da retomada da pesquisa arqueológica no município de Palestina de Goiás (Região Arqueológica de Caiapônia). Apesar da expressiva abrangência temática da pesquisa na região, este trabalho foca na variabilidade tecnológica presente nos conjuntos líticos de dois sítios da região: GO-Cp-16 e GO-Cp-17 e seus aspectos geomorfológicos. Esses sítios são relacionados ao período do Holoceno Médio e Recente. A cultura material aqui analisada foi, majoritariamente, obtida pelas escavações realizadas entre 1979 e 1981. Também trazemos reflexões sobre o contexto macrorregional em que estes sítios se encontram.
\end{abstract}

\begin{abstract}
In this article we present the initial results arising from the resumption of archaeological research in Palestine of Goiás (Archaeological Region Caiapônia). Despite the significant thematic of the research in the region, this work focuses on technological variability present in the lithic sets of two sites in the region: GO-Cp-16 and GO-Cp-17 and geoarchaeological aspects. These sites are related to the Middle Holocene period and the material culture analyzed here was mostly obtained by excavations carried out between 1979 and 1981. We also reflects on the macro regional context in which these sites are.
\end{abstract}

Recebido em 11 de maio de 2016. Aprovado em 08 de agosto de 2016.

\section{Introdução}

A opulência arqueológica do sudoeste do Estado de Goiás, em especial das regiões arqueológicas de Caiapônia, Jussara, Rio Verde e Jataí, foi constatada pelos primeiros arqueólogos, na década de 1970, por meio do Programa Arqueológico de Goiás (PAG) ${ }^{1}$, quando localizaram uma quarentena de sítios arqueológicos de naturezas distintas (manifestações rupestres, líticos, lito-cerâmicos e cerâmicos), implantados nos diferentes componentes ambientais da região (Figura 1).

Neste artigo, não exaurimos a complexidade ocupacional da região, tendo em vista que a pesquisa se encontra em andamento. Antes, trabalhamos com recortes espaciais, sítios GO-Cp-16 e GO-Cp-17, distantes entre si por cerca de $300 \mathrm{~m}$; recortes temporais (Holoceno Médio); e recortes materiais, uma vez que os conjuntos líticos aqui tratados são provenientes, exclusivamente, das escavações de 1979 a 1981. Os materiais das escavações posteriores estão em fase de análise e processamento de dados. Desenvolvemos, igualmente, no presente trabalho, considerações acerca do contexto geoarqueológico em que esses sítios estão inscritos. E, em uma perspectiva mais ampla, ensaiamos reflexões iniciais sobre as relações que esta região estabelece com outras áreas de entorno.

\footnotetext{
* Docente e pesquisadora da Pontifícia Universidade Católica de Goiás (PUC-Goiás) - Instituto Goiano de Pré-História e Antropologia e Programa de Pós-Graduação em Mestrado em História. E-mail: sibeli@pucgoias.edu.br.

*** Bacharel em Arqueologia pela Pontifícia Universidade Católica de Goiás (PUC-Goiás) e Mestre em História pela Universidade Federal de Goiás. Doutorando na Universidade de Paris X - Nanterre. E-mail: argonauta128@gmail.com.

**** Docente e pesquisador da Pontifícia Universidade Católica de Goiás (PUC-Goiás) - Instituto Goiano de Pré-História e Antropologia e Programa de Pós-Graduação em Mestrado em Ciências Ambientais e Saúde da PUC-Goiás. E-mail:rubin@pucgoias.edu.br.

**** Docente e pesquisadora da Pontifícia Universidade Católica de Goiás (PUC-Goiás) - Instituto Goiano de Pré-História e Antropologia e Programa de Pós-Graduação em Mestrado em Ciências Ambientais e Saúde da PUC-Goiás. E-mail: mairabrb@pucgoias.edu.br.

***** Docente e pesquisador da Universidade de Paris X - Nanterre,. E-mail: boeda.eric@gmail.com.
} 


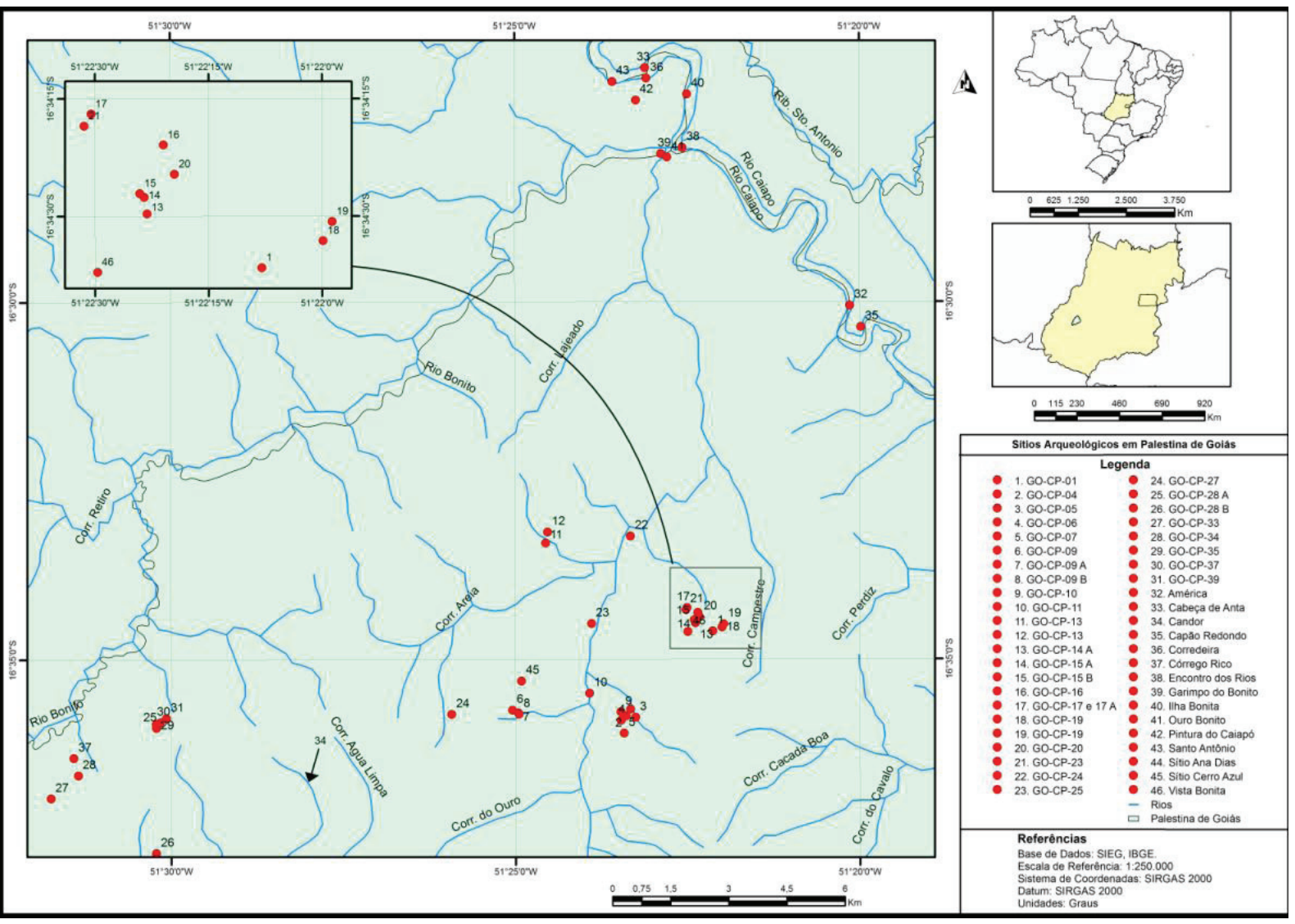

Figura 1 - Sítios arqueológicos localizados na região de Palestina de Goiás Fonte: Elaborada pelos autores.

\section{Breve Histórico das Pesquisas Arqueológicas na Área de Estudo}

As primeiras pesquisas arqueológicas realizadas pelo Programa Arqueológico de Goiás consistiram na implantação de oito projetos em diferentes áreas do antigo Estado de Goiás. O Programa foi desenvolvido, a partir da década de 1970, sob a influência do Programa Nacional de Pesquisas Arqueológicas (Pronapa), o qual, embora não tenha sido implantado em Goiás, influenciou as pesquisas arqueológicas iniciais realizadas pela Pontifícia Universidade Católica de Goiás (MELLO; VIANA, 2006).

Dentre esses projetos, centraremos nossa investigação no Projeto Alto Araguaia, no seio do qual se desenvolveu o Projeto Caiapônia, que visava a estudar os abrigos com pinturas que foram encontrados à margem esquerda do Rio Caiapó. Para tanto, foram abertas, entre os anos de 1979 e 1981, pequenas escavações nos sítios com pinturas que apresentavam solo ocupacional. A retomada de pesquisa na região arqueológica de Caiapônia teve início com a análise do material lítico de acervo e trabalho de campo a partir de 2009, limitandose, desta vez, ao Município de Palestina de Goiás, bacias dos córregos do Ouro e Torres do Bonito². O seu prosseguimento teve, por primeira motivação, a posição espacial da região arqueológica de Caiapônia, considerada estratégica em relação às outras regiões do Brasil Central em função das bacias hidrográficas que a compõem e do potencial de sítios do entorno que permitem explorar questões relacionadas às ocupações pretéritas.

Essa retomada coincide com a finalização dos estudos arqueológicos na região Nordeste de Mato Grosso, vale do Rio Manso, quando a abordagem tecnofuncional (BOËDA, 2013) foi aplicada aos conjuntos líticos - cultura material predominante entre os sítios arqueológicos da região -, permitindo a identificação das estruturas técnicas dos sistemas de debitagem e façonagem constituintes de cadeias 
operatórias de produção de instrumentos líticos de sítios arqueológicos daquela região (VIANA, 2005; MELLO, 2005). Em tal perspectiva, entendemos que os conjuntos líticos são integrantes de esquemas técnicos, nos quais estão envolvidas não somente escolhas técnicas (LEMONNIER, 2002) mas também aprendizagens e habilidades que estão combinadas em redes flexíveis e abertas que permeiam as tradições culturais. Da mesma forma, esses conjuntos líticos estão imbricados em "fios de longa extensão", denominados por Simondon (1969) como "linhagens técnicas", que subjazem as estruturas técnicas dos instrumentos e se constituem por suas modificações, inovações ou mesmo rupturas ao longo do tempo.

O desenvolvimento das pesquisas arqueológicas nos diversos sítios de Caiapônia tem possibilitado interação de dados em âmbito local e sua ampliação a outras regiões. Tem-se buscado, em uma perspectiva regional, a integração dos diferentes horizontes culturais e cronológicos presentes em uma macrorregião de entorno para uma compreensão mais ampla acerca da tecnologia lítica e, neste sentido, fomentar as informações acerca dos processos de povoamentos dessa região Central do Brasil.

Além das pesquisas acadêmicas, registramse, para essa região, trabalhos de arqueologia preventiva, iniciados a partir de 2009, quando foram localizados, na bacia do rio Caiapó, outros 20 sítios arqueológicos (ROSSI, 2015).

\section{Contextualização Cultural}

Com o objetivo de realizar uma sucinta contextualização do potencial arqueológico de nossa área de estudos, delineamos uma macrorregião considerando um círculo de $400 \mathrm{~km}$ de raio, tendo como centro Palestina de Goiás ${ }^{3}$. Na análise das pesquisas circunscritas nesta área, embasamo-nos em sítios datados ${ }^{4}$ e em pesquisas finalizadas e/ ou publicadas (Figura 2). Focamos em uma breve apresentação dos conjuntos líticos, uma vez que o grau de detalhamento está limitado pela brevidade de nossa contextualização e pelos dados disponíveis nas obras consultadas. Justificamos, ainda, que não caracterizaremos os conjuntos líticos atribuídos aos sítios ceramistas, uma vez que buscamos entender melhor as ocupações mais antigas da região de Palestina de Goiás, datadas por Schmitz et al. (1986), em cerca de 4.500 AP (SI-6743). As datações superiores a tal limite foram consideradas tendo em vista que os referidos autores postularam a possibilidade de a região apresentar ocupações do Holoceno Inicial.

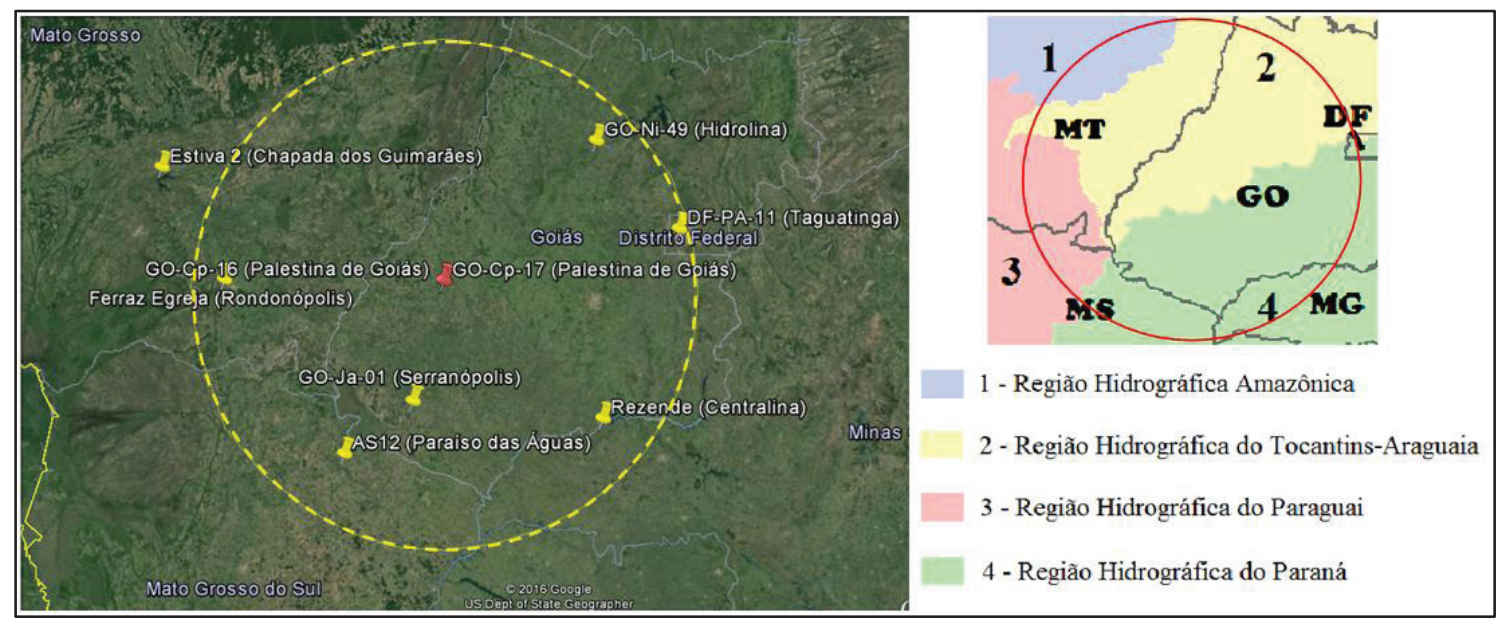

Figura 2 - Localização dos sítios arqueológicos da macrorregião com seus respectivos municípios Fonte: Google Earth (2016) e Agência Nacional das Águas (2016).

A macrorregião se estabelece na intersecção de quatro grandes regiões hidrográficas: Paraná, Paraguai, Tocantins-Araguaia e Amazônica (Figura
2). Essa posição se caracteriza em uma potencial área de enclave, favorecendo o potencial de gêneses ${ }^{5}$, trocas e convergências técnicas ${ }^{6}$ - a invenção independente, 
em um mesmo período ou em período mais recente, de uma mesma solução técnica em lugares diferentes (CHEVRIER, 2012) - que poderiam ter ocorrido devido à expressiva multiplicidade ambiental e cultural presente na área, mas que, no atual estágio das pesquisas, não foi possível definir.

Em uma perspectiva diacrônica, consideramos que os conhecimentos detalhados dos níveis técnico (produção) e funcional (instrumentação) de distintos conjuntos líticos são importantes para o desenvolvimento de considerações acerca das possíveis conexões técnicas (entre esquemas mentais, métodos e técnicas). Os contatos culturais e/ou circulações populacionais podem ser aventados no cruzamento de dados obtidos, não ignorando, contudo, as potenciais convergências/reinvenções técnicas originais em cada área estudada. Assim, trabalhamos com a hipótese de que Caiapônia - próxima às referidas bacias hidrográficas - poderia ser considerada como região "facilitadora" de trocas culturais.

As ocupações da transição do Pleistoceno/ Holoceno e Holoceno Inicial, presentes nesta área, estão representadas por sítios nos municípios de Serranópolis/GO, Paraíso das Águas/MS (Alto Sucuriu) e Hidrolina/GO, todos localizados em abrigos rochosos. Um sítio do Distrito Federal (Taguatinga), localizado em ambiente aberto e sem data de ocupação ${ }^{7}$, também foi considerado. Os sítios de Serranópolis (SCHMITZ; ROSA; BITENCOURT, 2004) e do Alto Sucuriu (MARTINS; KASHIMOTO, 2012) guardam certas semelhanças, entre elas: a ocupação em abrigos rochosos, a utilização de matéria-prima dos próprios abrigos para produção de ferramentas e as características técnicas da cultura material lítica. São recorrentes, em ambas as regiões, os instrumentos façonados unifacialmente a partir de uma face plana, as "lesmas", definidas em Schmitz, Rosa e Bitencourt (2004). Elas apresentam uma diversidade de volumes e potenciais funcionais. Em Serranópolis, são também descritos, para este período, esquemas técnicos de instrumentos sobre lascas sem a presença de façonagem. Trata-se de instrumentos de volumes alongados, tendo suas unidades tecnofuncionais transformativas situadas ao longo de um dos lados, enquanto a área preensiva se configura, em geral, como dorso abrupto, localizado em direção oposta (LOURDEAU, 2013). Em Sucuriu e Serranópolis, há ainda a presença de instrumentos trabalhados bifacialmente; todavia, eles são raros.

Os conjuntos líticos de Hidrolina estão presentes no sítio em abrigo GO-NI-49, situado a norte do Estado de Goiás (BARBOSA, SCHMITZ; MIRANDA, 1976/1977). A datação para o sítio é de 10.750 \pm 300 AP (SI-2769) e, embora apresente instrumento cujas características específicas se assemelham à estrutura técnica de produção de plano-convexos, façonados unifaciamente, com mais de uma sequência de retiradas, constatamos diferenças em relação aos sítios apresentados anteriormente. Dentre elas, destaca-se a superfície de ataque do referido instrumento, constituída pelo aproveitamento do neocortex de seixo fluvial. Pela análise diacrítica da peça, também constatamos que uma última fase de confecção do instrumento alterou a estrutura original, representando uma mudança tecnofuncional importante no instrumento.

Destaca-se, ainda, como elemento diferenciador, a presença de conjuntos líticos produzidos majoritariamente $(95 \%$ do total da coleção) em quartzo, com características distintas (poliédrico e com graus variados de microfraturas) e de procedência local, com indícios da rocha encaixante (xisto). Além disso, há quartzo leitoso em suporte não identificado e hialino, em cristal de rocha, provenientes de outros locais. Foram identificados, ainda, materiais em quartzito (em suporte de seixo rolado e em bloco) e em sílex, ambos em pouca quantidade. Trata-se de objetos líticos de pequenas dimensões, lascas de quartzo leitoso e hialino, de boa qualidade para o lascamento, que também foram utilizadas como instrumentos. Nesses casos, o gume foi utilizado na sua forma bruta ou retocado com poucas sequências de negativos. Os suportes desses instrumentos provêm de debitagem, cujos métodos de lascamento ainda não foram precisados. Todavia, destaca-se a produção unipolar, com percutor duro, produzindo lascas de dimensões pequenas, de talões lisos, apresentando pontos de impactos bem marcados, bulbos definidos e perfis levemente côncavos. De forma menos expressiva, fazse presente a debitagem bipolar sobre bigorna. 
Finalmente, trazemos os conjuntos do sítio lítico DF-PA-11, localizado em área aberta, no vale do córrego Taguatinga, Distrito Federal (SOUZA, 2015). A análise inter-relacional dos núcleos, instrumentos e lascas, distribuídas em níveis estratigráficos entre 20 e $30 \mathrm{~cm}$, identificou e caracterizou esquemas técnicos para produção dos suportes (debitagem) e outros para a confecção de instrumentos. Os núcleos foram explorados a partir do aproveitamento da angulação e convexidades naturais dos blocos, com retiradas agenciadas unidirecionalmente em grande parte do material analisado - tipo " $\mathrm{C}$ ", segundo Böeda (2013). A partir dessas características, foi implantado um conjunto de esquemas técnicos particulares. Constatamos que a percussão nos núcleos é exclusivamente interna, direta e com percutor duro.

Sobre a confecção dos instrumentos, observamos que $13 \%$ do total da coleção estudada apresentam evidências de façonagem. Os suportes deles são em lascas inteiras ou em estado fragmentado e peças provenientes de alteração térmica. Há a hipótese de que as lascas-suporte mais volumosas, utilizadas na produção de instrumentos planoconvexos com faconagem unifacial, tenham sido provenientes dos afloramentos fixos, localizados na própria área do sítio. Tais instrumentos apresentam estrutura técnica e esquemas de produção e funcionamento semelhantes aos instrumentos mais antigos de Serranópolis. No entanto, não há datação no sítio para corroborar tal hipótese. Os demais instrumentos apresentam uma lógica técnica, constituída por um bordo, com dorso localizado em direção oposta a um gume, de natureza transformativa e de menor angulação. Destaca-se, ainda, a reutilização contundente de parte dos núcleos como percutores ou bigornas (SOUZA, 2015).

Sobre os sítios do Holoceno Médio circunscritos na área definida, destacamos sítios dos municípios de Serranópolis/GO, Chapada dos Guimarães (vale do rio Manso), Rondonópolis/MT e Centralina/GO. Os sítios destas localidades estão em abrigos rochosos, com exceção de Manso, que apresenta sítios em abrigos e em ambientes abertos. Entre os sítios de Serranópolis, foi identificada uma diminuição dos instrumentos façonados unifacialmente, tendendo à ausência destes nas camadas iniciais deste período, o que levou os pesquisadores a proporem um fenômeno de "ruptura técnica" para este momento transicional (SCHMITZ; ROSA; BITENCOURT, 2004). O "Tecnocomplexo Itaparica" (fase Paranaíba) teria dado lugar, durante a transição para o Holoceno Médio, à produção de instrumentos sobre lasca sem normalização volumétrica evidente (fase Serranópolis) (LOURDEAU, 2010). Novas pesquisas em curso trazem a lume outras possibilidades de entendimento, levando-nos a enriquecer nosso conhecimento acerca da variabilidade técnica dos conjuntos líticos do Holoceno Médio (fase Serranópolis) (RAMOS; VIANA, 2016).

No Alto Sucuriu, as datações relativas ao Holoceno Médio estão relacionadas a artefatos confeccionados em matéria-prima de arenito silicificado avermelhado e silexito de cascalhos fluviais. Pelos dados relativos às coleções apresentadas em Martins e Kashimoto (2012), foi também observada a presença de suportes alongados e façonados.

Ainda no Holoceno Médio, temos os sítios do vale do rio Manso, dentre eles o sítio Estiva 2, datado por volta de 6 mil anos. O sítio está em ambiente aberto, nele há uma diversidade de matéria-prima, que teria sido transportada ao sítio. Objetos em seixos de arenito silicificado e blocos de sílex perfazem o maior número, além de outras matérias-primas em menor proporção, como o quartzo, argilito e siltito. Os núcleos foram explorados pela concepção de debitagem "C" (BOËDA, 2013), apresentando, em geral, duas sequências de lascamentos independentes entre si, fornecendo de duas a três lascas. Também são encontradas na coleção, em proporção bem menor, lascas em seixo de quartzito, derivadas de método de exploração bipolar sobre bigorna. Quanto aos instrumentos, a maior quantidade é em sílex e em suporte de lascas. A produção de suporte com dorsos caracteriza a concepção volumétrica de vários dos tecnotipos de instrumentos definidos para este sítio. Destaca-se, ainda, a presença de instrumento plano-convexo, façonado unifacialmente, localizado em outro sítio da região (sítio São José), não datado. Este instrumento foi considerado intrusivo, haja vista 
não ter indícios técnicos de sua produção no local (MELLO, 2005).

No estado de Mato Grosso, destacam-se, no Holoceno Médio, os sítios de Rondonópolis, dentre eles o Ferraz Egreja que, que está em abrigo sob rocha. Nele foi evidenciada uma sequência de ocupações ininterruptas que remontam a um período também de cerca de 6 mil anos AP (VIALOU, 2006). Neste sítio, assim como entre os sítios de Manso e diferente de Serranópolis, há uma variedade de matériasprimas rochosas, a saber: sílex, arenito silicificado, quartzito, quartzo e hematita (VIALOU; FIGUTI, 2013). O aprovisionamento da matéria-prima encontra-se em áreas de, no máximo, $20 \mathrm{~km}$ de raio. Os blocos e os grandes seixos que serviram de núcleos foram reduzidos fora do sítio, o que é indicado pela ausência das grandes lascas corticais nas escavações. Os núcleos identificados se encontram praticamente esgotados. Não há desperdício de material no sítio, informação que foi proposta a partir do cruzamento dos dados relativos à qualidade da matéria-prima (entre ótima e boa) e à aplicação dos gestos de lascamento (apreendidos por meio da análise dos talões) (VIALOU, 2006). Os instrumentos identificados, produzidos principalmente sobre lascas de arenito, são "[...] raspadores com retoques em escamas, raspadores com retoques lamelares, peças com reentrâncias, denticulados, peças com retoques bifaciais, plano-convexos" (VIALOU, 2006, p. 172). Ainda, segundo a autora, foram encontradas lascas desprovidas de retoques, apresentando marcas de utilização (microrretoques de desgaste, lustro e polimento do bordo ativo).

O sítio arqueológico a céu aberto Rezende, localizado no curso médio do vale do rio Paranaíba, município de Centralina (MG), apresentou dois horizontes ocupacionais distintos. Os estratos mais antigos são exclusivamente líticos, datados entre 4.950 e 4.250 anos AP (zona 1) e entre 7.300 e 3.680 anos AP (zona 2). As matérias-primas utilizadas foram o arenito-silicificado, seguido do sílex, quartzo e calcedônia. As peças líticas foram descritas como "leves e bem retocadas" (ALVES, 2013, p. 111), com dimensões entre 3 e $8 \mathrm{~mm}$. A debitagem foi realizada com percussão direta, com percutor duro e os instrumentos teriam sido retocados produzindo lascas curtas de angulação semiabrupta, e em forma de escamas. Os instrumentos considerados pelos pesquisadores como mais representativos do sítio foram os raspadores sobre lascas, seguidos pelos plano-convexos (lesmas).

\section{Caracterização geológica e vegetacional da região de Palestina de Goiás}

A ocupação humana pretérita na região de Palestina se estabeleceu em três principais contextos geológicos: em afloramentos formados por depósitos de conglomerados ou diamictitos, os quais têm sido denominados de "campos de seixos"; nos abrigos areníticos provenientes de rochas sedimentares da porção basal da Bacia Sedimentar do Paraná; e nas áreas de ocorrência dos granitos pré-Cambrianos definidos adiante. No contexto geológico, a Bacia Sedimentar do Paraná apresenta um espesso pacote de camadas paleozoicas depositadas sobre corpos graníticos do pré-Cambriano. Os abrigos se desenvolveram em testemunhos e rochas areníticas da Formação Furnas, datada do Eo-Devoniano. Nesta região, os arenitos da Formação Furnas, apresentam contato inferior com sedimentos da Formação Vila Maria, do Grupo Ivaí, de ocorrência restrita na bacia, datada do Eo Siluriano (ALMEIDA; BRITO-NEVES; CARNEIRO, 2000; PEREIRA, 1998; PEREIRA et al., 2012).

$\mathrm{Na}$ área de estudo, as rochas da Formação Vila Maria são representadas por folhelhos com registros fósseis e, principalmente, diamictitos que correspondem a conglomerados com seixos arredondados a subarredondados de diferentes rochas, entre elas quartzitos, granitos, sílex e rochas básicas e ultrabásicas, constituindo uma estreita faixa com largura máxima da ordem de $40 \mathrm{~m}$, posicionada estratigraficamente acima dos granitos NeoProterozoicos, que ocorrem na porção mais baixa do vale, em direção ao Córrego do Ouro (PEREIRA, 1998; MILANI et al., 2007, PEREIRA et al., 2012). Esses diamictitos, embora de ocorrência restrita, afloram em uma faixa bem definida, situada entre a área de ocorrência dos arenitos da Formação Furnas e os granitos pré-Cambrianos. São passíveis de mapeamento e localização, constituindo, segundo a perspectiva arqueológica, os "campos de 
seixos" e a principal fonte de matéria-prima para a elaboração de instrumentos líticos das populações pretéritas da região.

No decorrer do Paleozoico, o desenvolvimento dos sistemas de fraturamento contribuíram, no decorrer dos processos de intemperismo, para a queda de blocos que deram origem aos abrigos. Este processo é bastante evidente no abrigo GO-Cp-16, desenvolvido sobre um testemunho de arenito da formação Furnas que apresenta um extenso paredão posicionado segundo a direção Norte/Sul, com altura da ordem de $10 \mathrm{~m}$ e registros de pinturas rupestres. Aparentemente, correspondia a um abrigo com um substrato originalmente irregular, com queda acentuada do relevo da base do testemunho em direção ao vale. A queda de blocos junto à parede do abrigo promoveu a formação de espaços e áreas menos acidentadas, possibilitando a formação de áreas de ocupação humana que são objetos de escavação, fornecendo um conjunto expressivo de registros arqueológicos.

Quanto à paisagem vegetacional da área, foi caracterizada a partir da classificação de fitofisionomias do bioma Cerrado, estabelecidas por Ribeiro e Walter (2008). Nesse sentido, embora a região apresente, atualmente, alto índice de antropização, é possível, através da presença de áreas residuais da vegetação original, inferir sobre as diferentes fitofisionomias ocorrentes, provavelmente nos últimos mil anos AP. Dessa forma, nas porções mais baixas, junto ao Córrego do Ouro, ocorrem relictos de matas de galeria. Esta vegetação é circundada por formações savânicas, representadas por cerrado típico nas áreas de relevo mais aplanado e por cerrado denso nas áreas situadas entre os abrigos, onde vigoram condições mais úmidas. No topo dos testemunhos de arenitos, observa-se a presença de cerrado rupestre, que em conjunto com outras fitofisionomias savânicas, forma um mosaico.

\section{Caracterização dos Sítios Arqueológicos e da Cultura Material}

\section{Sítio GO-Cp-17}

Conforme citado na caracterização geológica da área, o sítio GO-Cp-17 se estabeleceu sobre um local de ocorrência dos conglomerados e diamictitos da formação Vila Maria, e outros quatro sítios foram encontrados neste tipo de ambiente. A espessura da sequência total dos diamictitos no local não foi possível de ser estabelecida, uma vez que a escavação foi interrompida por volta de $35 \mathrm{~cm}$ de profundidade, sem a presença de material arqueológico. A partir desse ponto, verifica-se uma mudança no contexto geológico, com a presença de unidade bastante alterada, de cor avermelhada, sugerindo processos de laterização, sem ocorrência de seixos, provavelmente relacionada à alteração dos granitos pré-Cambrianos.

$\mathrm{O}$ material arqueológico se restringiu àqueles de natureza lítica. O sítio se apresenta enquanto ambiente de palimpsesto, e a pesquisa ainda está em andamento.

\section{Cultura Material Lítica}

Neste sítio, está presente uma diversidade expressiva de implementos líticos, constituintes dos diferentes momentos de cadeias operatórias de produção de instrumentos lascados. Apresentaremos resultados da análise de material proveniente das escavações realizadas entre 1979 e 1981: 10 percutores, 24 núcleos, 119 instrumentos, 597 lascas e 1.005 fragmentos de lascas e refugos múltiplos decorrentes do processo de lascamento. A matériaprima predominante foi o quartzito, seguido do quartzo e sílex.

Tendo em vista os limites do presente artigo, a cultura material lítica será apresentada em duas vertentes: 1) escolhas técnicas incididas da seleção dos seixos e da produção dos suportes para instrumentos; 2) escolhas advindas da confecção de instrumentos. Para ambos os casos, selecionamos alguns dados para apresentação.

\section{Escolhas técnicas: os seixos e a produção dos suportes para instrumentos}

A partir da análise do neocórtex presente nas diferentes classes dos materiais líticos, observamos a escolha preferencial de seixos com características volumétricas particulares, as quais se relacionam a instrumentos específicos. Tais seleções se voltaram 
a duas categorias principais de seixos: uma delas caracterizada por superfície superior e inferior planas, com laterais abruptas, definindo objetos modulares; a outra, pela escolha de seixos alongados e de superfícies convexas (VIANA et al., 2015).

Os seixos planos entraram no circuito técnico de confecção de instrumentos por meio de façonagem de seixo, produzindo instrumentos específicos. Modificações de áreas particulares criavam as condições para a instalação de unidades tecnofuncionais transformativase, por vezes, unidades preensivas. É possível, ainda, que no processo de confecção, lascas corticais e secundárias tenham sido escolhidas como suporte para instrumentos diversos. Seixos convexos também foram escolhidos para confecção de instrumentos por façonagem. No entanto, neste artigo, não serão apresentadas as cadeias operatórias correspondentes à confecção de instrumentos em seixos convexos, mas apenas a utilização destes seixos como núcleos, para produção de lascas suportes.

Tais núcleos (24 peças) foram explorados por esquemas técnicos que possuem, como similaridade, o fato de não preverem uma configuração inicial e são descritos por Boëda (2013) como núcleos do tipo "C". A exploração transcorreu aproveitando as características naturais da própria matriz, previamente selecionada por apresentar extremidades aplainadas para atuar como plano de percussão e superfícies convexas, neste caso, aproveitadas como superfícies de debitagem para predeterminação das lascas. As sequências de lascamento foram curtas. Estes seixos também foram explorados pela debitagem bipolar. Neste caso, o posicionamento do seixo é, necessariamente, no sentido longitudinal e as convexidades apicais, mais aguçadas, foram essenciais para atuar como área de percussão e de apoio.

No sítio em questão, os seixos convexos também foram escolhidos como matrizes de concepção de debitagem do tipo "D" Manso, cujas características podem ser conferidas em Viana et al. (2014). No sítio GO-CP-17, foram identificadas sete lascas provenientes desta concepção de debitagem, com marcas de utilização no gume.

\section{Escolhas técnicas: confecção de instrumentos}

A confecção de instrumentos do sítio GOCp-17 é constituída por esquemas técnicos diversos. No entanto, as variações volumétricas dos suportes correspondem a instrumentos específicos. Esta diversidade é entendida como opções e soluções particulares das culturas. Reconhecemos que a concepção volumétrica de uma área transformativa de um instrumento é constituída pela integração de três elementos: 1) o fio do instrumento (plano de bico); 2) a área que antecede o fio (plano de corte); e 3) a superfície de ataque (a base) (BOËDA, 2013). Estes elementos atuam em sinergia e com papéis distintos, fornecem a base para a ação técnica do instrumento se realizar, seja ela a de cortar, de raspar, de furar ou de percutir8. O plano de bico se caracteriza pelo "fio" que entra em contato direto com a matéria a ser transformada; o plano de corte proporciona apoio e direcionamento para a ação técnica se concretizar; a superfície de ataque, por sua vez, está integrada às demais, proporcionando meios de controle para a penetração do diedro de corte na matéria (LOURDEAU, 2010). A concepção da zona preensiva, seja no caso das ferramentas de uso manual sem encabamento, seja no caso daquelas que recebem encabamento, são consideradas imperativas na constituição de um instrumento. Elas são responsáveis pelo funcionamento do instrumento e nem sempre são fixas, podendo desempenhar funções duplas: de deter o papel de manuseio (preensão) e de ação técnica transformativa.

Pelas análises tecnológicas das ferramentas do sítio em questão, foram identificadas diversas cadeias operatórias. Apresentaremos somente três delas:

1) Confecção de instrumento de estrutura técnica assimétrica, compreendida por uma área abrupta (dorso) oposta à zona de instalação do gume transformativo.

Está representada por oito instrumentos de quartzito, medem em média $58 \mathrm{~mm}$ x $63 \mathrm{~mm}$ x 32 $\mathrm{mm}$. Os suportes são compostos por fragmentos poliédricos e lascas volumosas, de talões espessos e/ou laterais naturais, $90 \%$ das peças apresentam 
córtex na lateral e em $20 \%$ esta área foi produzida na fase de debitagem. Em todos os casos, são espessos e aprumados. Aqui, há importante integração das escolhas técnicas realizadas do início da cadeia operatória, com a escolha dos seixos, até as últimas fases do processo técnico, relacionado ao seu funcionamento.

São objetos técnicos assimétricos, os quais guardam uma lógica técnica particular e predeterminada no momento da debitagem: a área abrupta está em direção oposta à área de menor angulação. Esta dupla está diretamente relacionada ao funcionamento do instrumento, estando as áreas mais avantajadas (dorsos) vinculadas à preensão de força. A relação percentual média entre a dimensão transversal da menor seção (medida no limite entre planos de corte e bico) para a de maior seção (na lateral abrupta, dorso) é de $52 \%$, ou seja, a dimensão menor corresponde a $52 \%$ da maior.

O plano de corte e de bico de todos os instrumentos foi confeccionado em momento específico de instalação das unidades tecnofuncionais transformativas, produzindo, em geral, gumes côncavos, de angulação abrupta e com uma única sequência de retiradas. Já as superfícies de ataque, em oito peças, foram produzidas durante a debitagem da lasca e, em um caso, foram confeccionadas após a retirada da lasca suporte. Há lascas de retoque no sítio que poderiam estar relacionadas à confecção de tais instrumentos. Para a debitagem e confecção dos instrumentos, foram utilizados percutores duros, com percussão direta unidirecional e gestos internos. Os seixos escolhidos para este esquema técnico foram, principalmente, os de superfícies convexas.

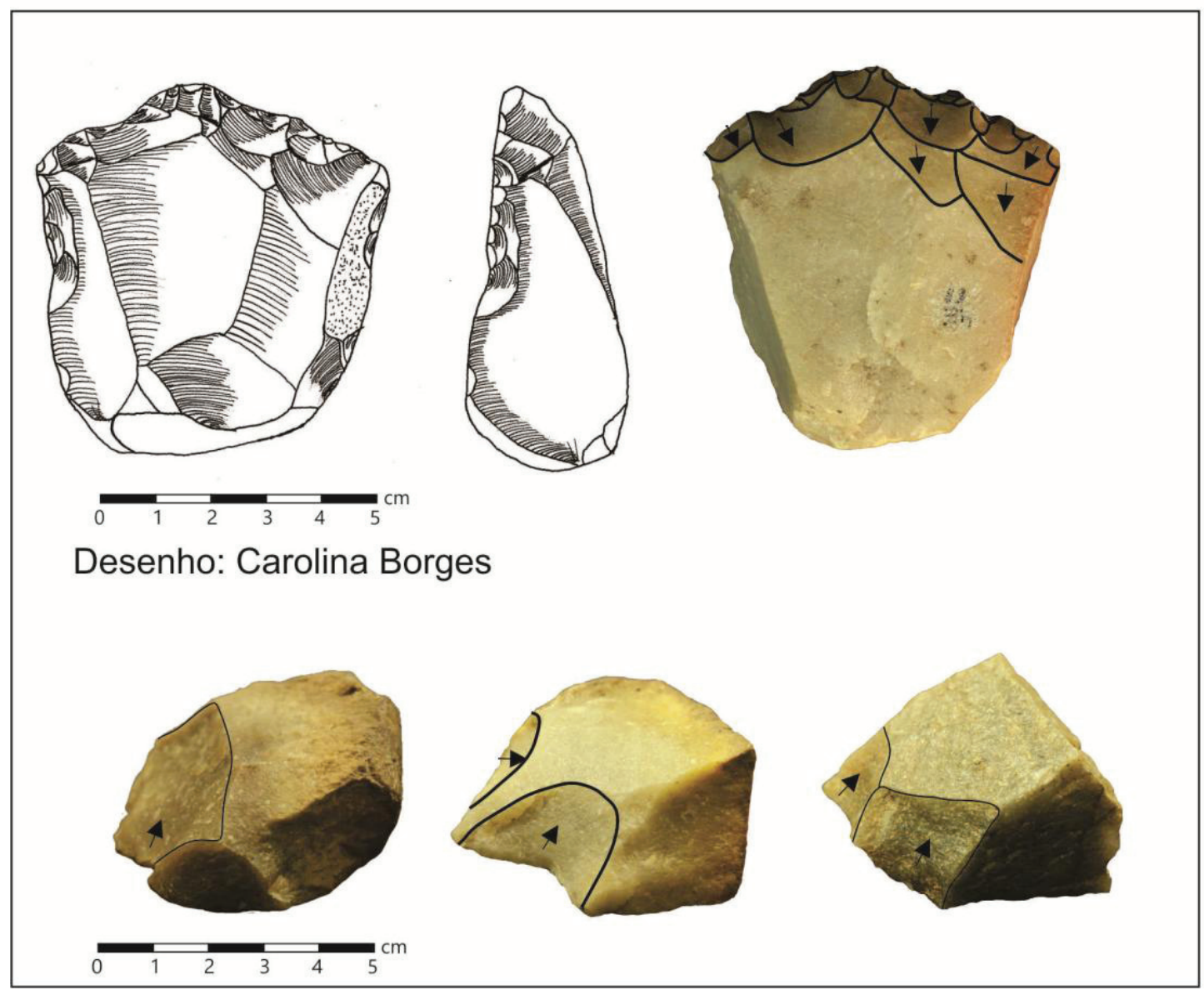

Figura 3 - Instrumentos representantes da cadeia operatória n. 1 (Sítio GO-Cp-17). Confecção de instrumento de estrutura técnica assimétrica, compreendida por uma área abrupta (dorso) oposta à zona de instalação do gume transformativo

Fonte: Elaborada pelos autores. 
2) Confecção de instrumentos cuja estrutura técnica foi definida a partir de façonagem unifacial à custa de uma superfície que tende ao aplainamento.

Está representada por nove instrumentos, sendo um em estado fragmentado, todos em quartzito. O suporte é em lasca volumosa, cuja superfície inferior tende ao aplainamento. As variações nas características do aplainamento das peças façonadas unifacialmente já haviam sido apontados por Fogaça e Lourdeau (2008) e ampliadas por Lordeau (2010). Contudo, as variações apontadas pelos pesquisadores não são suficientes para dar conta da variabilidade que identificamos nos instrumentos do GO-Cp-17. Nem sempre o eixo mais longo do instrumento coincide com o sentido tecnológico da lasca; o maior alongamento está em uma média de $7,3 \mathrm{~cm}$ e largura média de $4,1 \mathrm{~cm}$, consistindo em peças de contorno amendoado. O suporte destes instrumentos é caracterizado por lascas volumosas. A modificação do suporte é intensa e, em geral, há poucas informações técnicas sobre as características originais do suporte, tendo em vista a redução intensa do volume por sequência(s) de façonagem unifacial. São instrumentos com estrutura técnica semelhante às de Serranópolis, mas com variabilidades regionais acentuadas (VIANA; BORGES, 2014). Há indícios de utilização de percussão macia para façonagem e retoque, com gestos internos e periféricos. Devido à intensidade da exploração, $55 \%$ das peças não apresentam córtex e o restante não oferece indícios suficientes para precisar as características das superfícies do seixo selecionado, salvo uma peça, que apresenta em média $40 \%$ de córtex, o que permite inferir a seleção de um seixo de silhueta convexa, visto que tal característica foi aproveitada para a configuração final do instrumento.

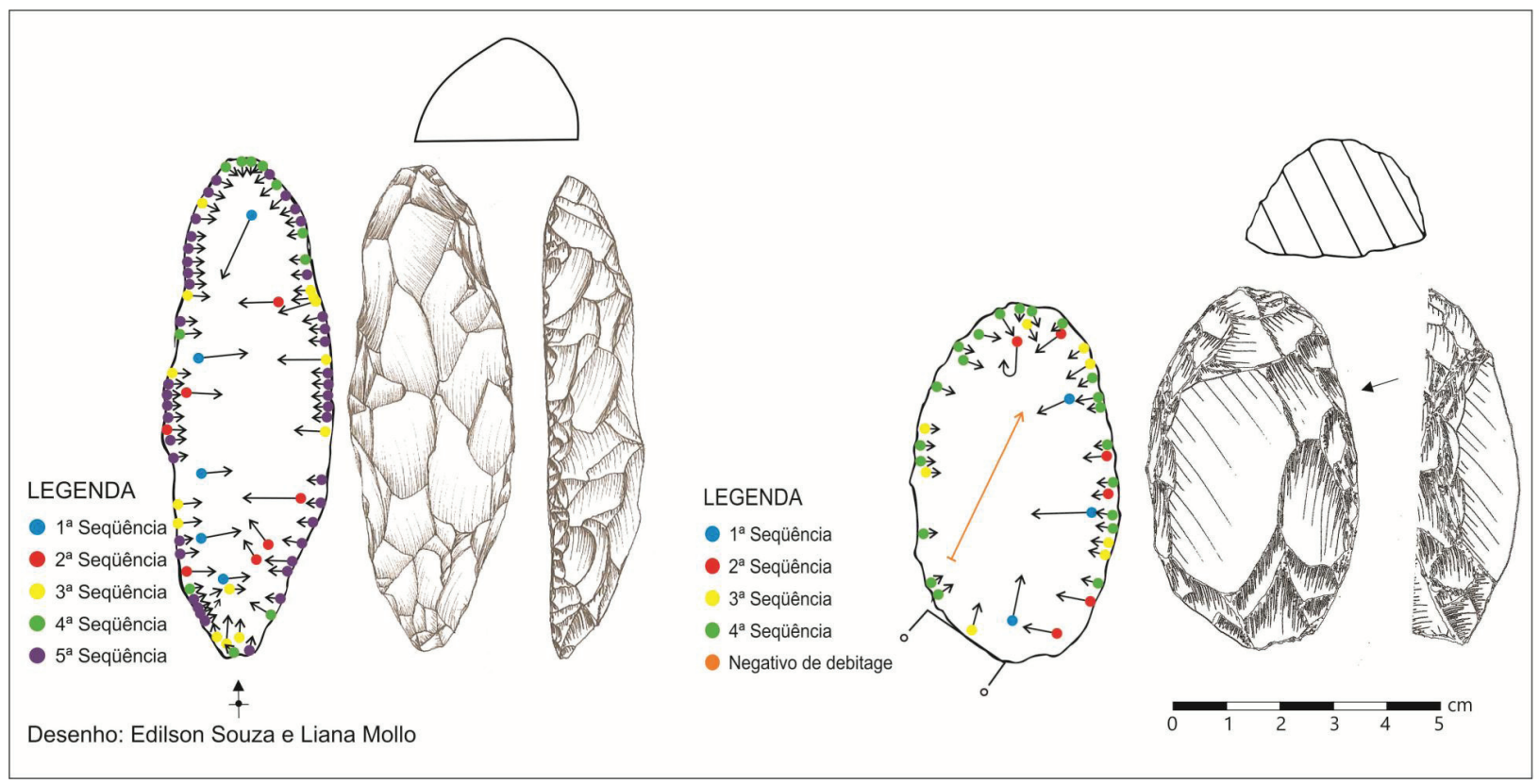

Figura 4 - Produção e intensidade de façonagem em instrumentos façonados unifacialmente (plano-convexos) do sítio GO-Cp-17

Fonte: Elaborada pelos autores.

3) Confecção de instrumento por façonagem de seixo de estrutura volumétrica modular

Trata-se de 29 instrumentos de quartzito, a média das dimensões é de $76 \mathrm{~mm}$ de comprimento, $58 \mathrm{~mm}$ de largura, $28 \mathrm{~mm}$ de espessura. Foram confeccionados a partir da escolha de seixos de faces inferior e superior planas. A façonagem foi realizada para a confecção de gumes transformativos (planos de corte e de bico) e/ou zonas preensivas, modificando a estrutura deste suporte. As ações técnicas foram realizadas com percutores duros, com percussão direta unidirecional e gestos internos, produzindo até três sequências de lascamento e gumes, em geral, de tendência retilínea ou côncava, com angulação 
predominante em torno de $80^{\circ}$. A superfície de ataque foi produzida em somente oito das peças, indicando que a face inferior plana, cortical, foi aproveitada, havendo, para tanto, um investimento forte no início da cadeia operatória, de seleção do seixo. Para este esquema, foram selecionados seixos estritamente de estrutura volumétrica modular9 Há, na coleção, lascas correspondentes à fase de confecção destes instrumentos.
Superficie de ataque produzida

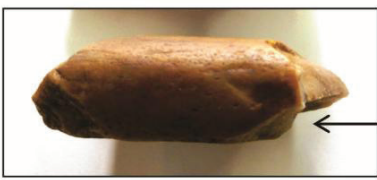

Escolha do seixo

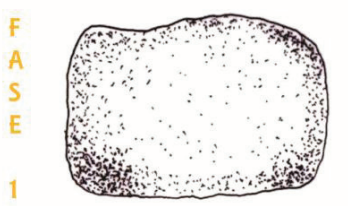

Produção de superfície de ataque

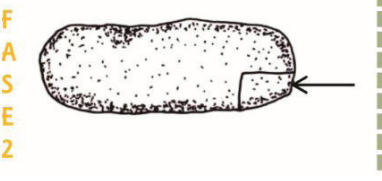

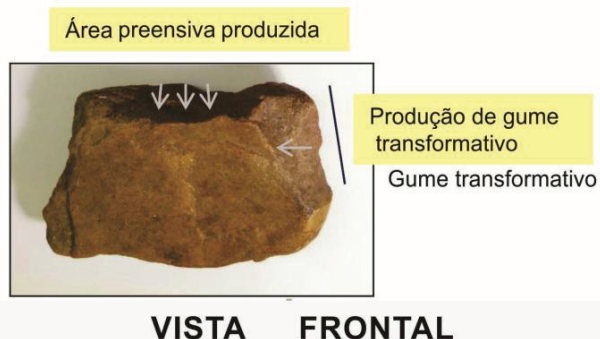

Gume e área preensiva produzidos produção de área preensiva

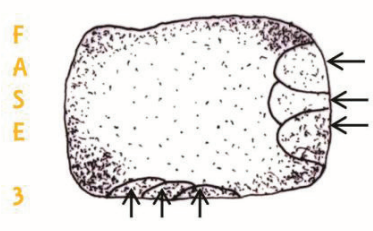

VISTA

\section{Produção de} área preensiva

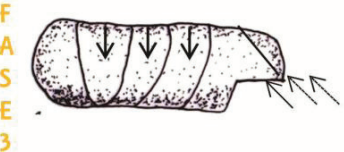

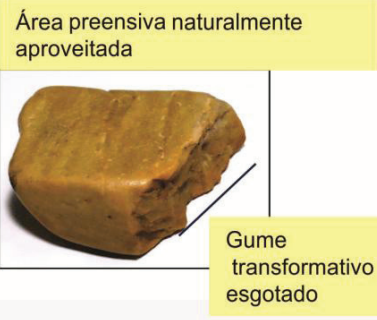

Afiação de gume

F

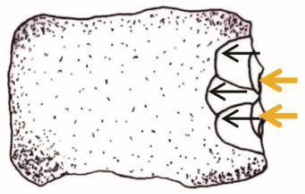

Área preensiva/ Superfície de ataque/ gume esgotado
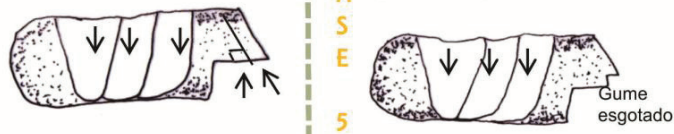

Figura 5 - Confecção de instrumento com façonagem em seixos Fonte: Elaborada pelos autores.

A coleção lítica do sítio GO-Cp-17 também possui registro de outras cadeias operatórias de confecção de instrumentos, entre elas aquela referente à seleção de suportes em detritos de lascamento, como lascas de façonagem e retoque, bem como refugos de debitagem. Neste caso, tais suportes são entendidos como provenientes de intenção tecnológica secundária.

\section{Sítio GO-Cp-16}

O sítio GO-Cp-16 encontra-se em abrigo situado em uma sequência de testemunhos rochosos em arenito. Apresenta cerca de $40 \mathrm{~m}$ de comprimento, $5 \mathrm{~m}$ de largura, com uma aba de proteção de, em média, $2 \mathrm{~m}$ de profundidade. Está em posição estratégica, destacando-se na paisagem. A partir dele, pode-se ter uma visão dos vários sítios arqueológicos do entorno. Rubin et al. (2016) argumentam que a área do sítio GO-Cp-04 sofreu uma substancial redução em consequência, principalmente, de processos erosivos, tanto na área abrigada quanto no talude frontal. Tal argumentação também pode ser aplicada ao GO-Cp-16, distante cerca de $4 \mathrm{~km}$, com base na semelhança entre os abrigos e na estruturação da paisagem.

Entre 1979 e 1981, foram escavados, por níveis artificiais de $10 \mathrm{~cm}$, três setores de $2 \mathrm{~m}^{2}$. A escavação foi interrompida quando se atingiu uma grande quantidade de blocos, a cerca de $60 \mathrm{~cm}$ de profundidade. Os trabalhos posteriores de escavação, cujos objetivos já foram expostos, consistem na abertura de outras três áreas, distribuídas na área protegida do abrigo e fora dela (Figura 6). 


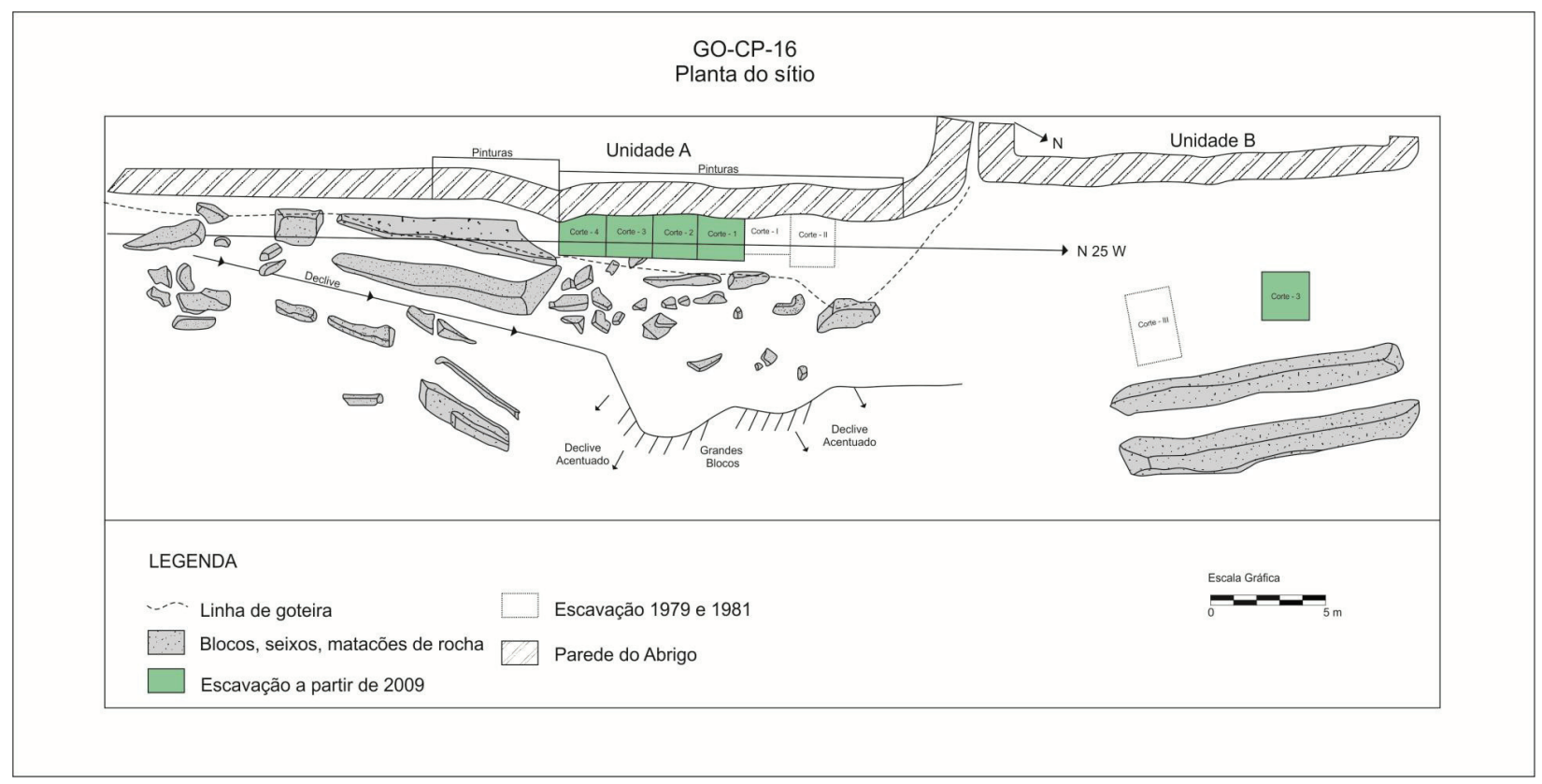

Figura 6 - Croqui do Sítio GO-Cp-16

Fonte: Elaborada pelos autores.

\section{Estratigrafia}

Nas primeiras escavações (1979 a 1981) do sítio GO-Cp-16, a estratigrafia do sítio foi caracterizada a partir de três camadas, a primeira húmica e as demais com vestígios ocupacionais. A cronologia do sítio foi identificada a partir da Camada 3, que acusou datação de $4.455 \pm 115$ AP (SI-6743), com materiais arqueológicos restritos ao lítico e ao carvão. Além desses, a segunda camada apresentou fragmentos cerâmicos. A caracterização atual da estratigrafia deste sítio tomou por base a leitura de paredes de dois cortes escavados a partir de 2009, Corte 4 (Unidade A) e Corte 1 (Unidade B), sendo este último localizado fora da área abrigada (Figura 6).

Optamos por trazer os dados referentes à Unidade A para complementar as descrições estratigráficas fornecidas por Schmitz et al. (1986). Embora os dados sejam parciais, tendo em vista que a escavação no sítio não foi finalizada, percebemos diferenças entre as camadas, como espessura, textura e bioturbação, que podem estar relacionadas às características do solo e ao fato de que a área sofreu, ao longo do tempo, processos naturais e ações antrópicas, como queda de blocos, erosão e deposição, bioturbação, caminho de gado e acampamento. Estas diferenças serão investigadas no decorrer da pesquisa, principalmente com o avanço das escavações e sua correlação com os materiais e a cronologia.

\section{Corte 4/Unidade A - Parede Sul (C-A)}

Foram identificadas, até o momento, três camadas, todas com ocorrência de material arqueológico. O perfil estratigráfico apresenta homogeneidade em relação à textura. As camadas 1 e 2 possuem grande quantidade de raízes com diâmetros variados e atividades de cupins, o que resulta na formação de lentes de coloração diferenciada, muitas vezes com maior dureza e coesão. $\mathrm{O}$ contato entre as camadas é gradacional ${ }^{10}$.

Camada 1: textura areia-siltosa (50\% areia, $45 \%$ silte e $5 \%$ argila), grãos predominantemente subarredondados e de baixa esfericidade, mineralogia a base de quartzo e concreção ferruginosa. Apresenta intensa bioturbação por raízes e cupins. Coloração seca: 7,5 YR 4/2 - marrom-escuro; coloração úmida: 7,5 YR 5/2 - marrom. Presença de grão de areia muito grossa e grânulos de quartzo.

Camada 2: textura areia-siltosa (40\% areia, $55 \%$ silte e $5 \%$ argila), grãos predominantemente 
subarredondados e de baixa esfericidade, mineralogia a base de quartzo e concreção ferruginosa. Bioturbação por raízes e cupins em menor intensidade que a Camada 1. Coloração seca: 5 YR 7/2 - cinza-rosado; coloração úmida: 7,5 YR 5/4 - marrom. Presença de grão de areia muito grossa e grânulos de quartzo e arenito, além de seixos de arenito.

Camada 3: textura areia-siltosa (50\% areia, $45 \%$ silte e $5 \%$ argila), grãos predominantemente subarredondados e de baixa esfericidade, mineralogia a base de quartzo e concreção ferruginosa. Pouca bioturbação por raízes e cupins em relação às Camada 1 e 2. Coloração seca: 5 YR 7/2 - cinza-rosado; coloração úmida: 7,5 YR 5/4 - marrom. Presença de grão de areia muito grossa e grânulos de quartzo e arenito.

\section{Corte 4 /Unidade A - Parede Norte (B-D)}

A camada 1 desta parede foi parcialmente escavada (Corte 3) e suas evidências podem ser observadas pela projeção do solo original, adjacente à parede. A ausência da Camada 3 certamente é explicada pelo fato de a escavação ainda não tê-la alcançado.

Camada 2: textura areia-siltosa ( $45 \%$ areia, $50 \%$ silte e $5 \%$ argila), grãos predominantemente subarredondados e de baixa esfericidade, mineralogia a base de quartzo e concreção ferruginosa. Bioturbação por raízes e cupins. Coloração seca: 5 YR 7/2 - cinza-rosado; coloração úmida: 7,5 YR 5/4 - marrom. Presença de grão de areia muito grossa e grânulos de quartzo e arenito, além de seixos de arenito, principalmente na base do perfil. Os blocos e matacões diminuem o campo de observação do perfil

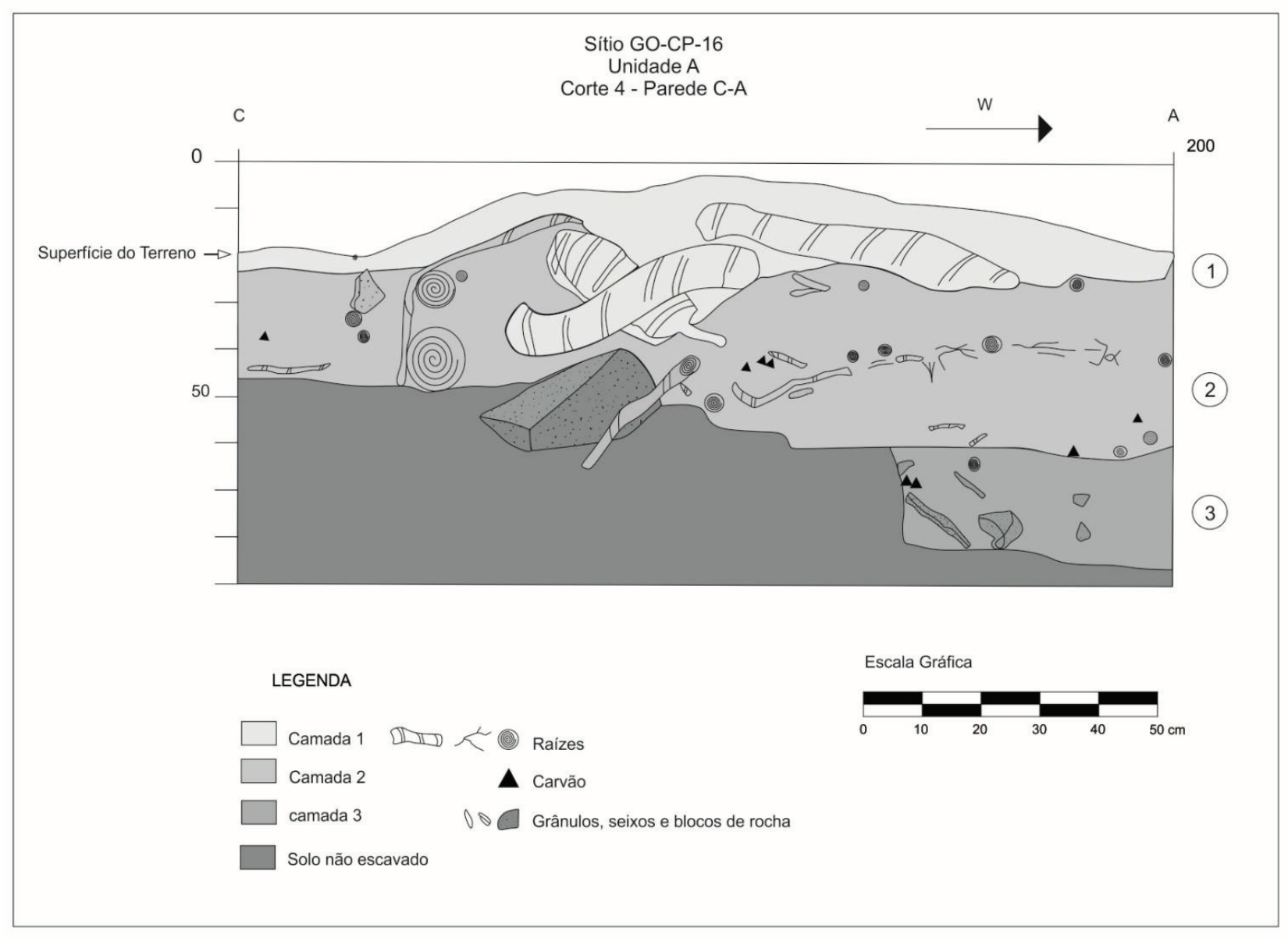

Figura 7 - Perfil Estratigráfico - Unidade A, Corte 4 /Parede Sul (C-A)

Fonte: Elaborada pelos autores. 


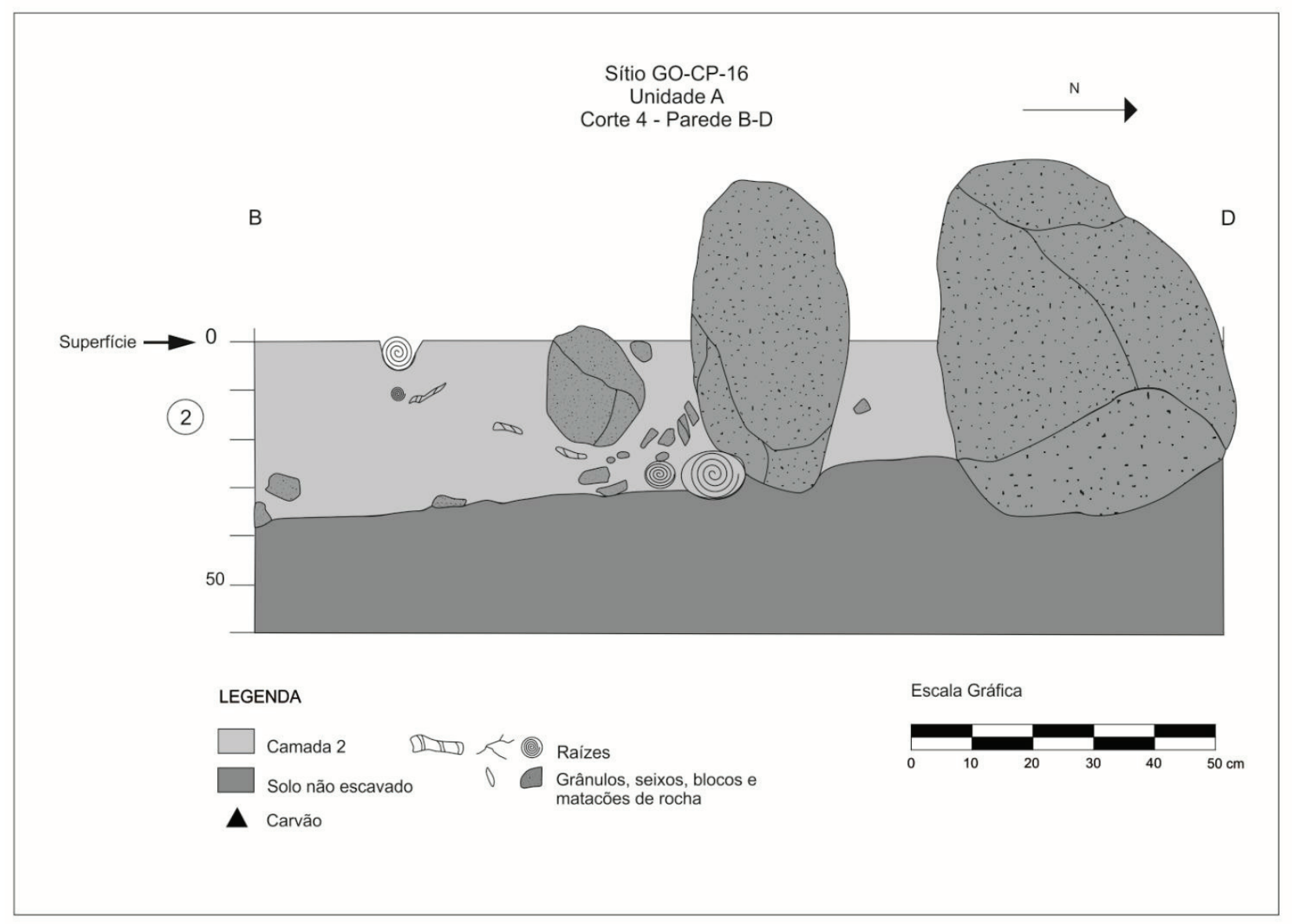

Figura 8 - Perfil Estratigráfico - Unidade A, Corte 4/Parede Norte (B-D)

Fonte: Elaborada pelos autores.

\section{Cultura Material lítica}

A cultura material predominante é de natureza lítica, representada nas matérias-primas de quartzito, seguido do quartzo e, de forma pouco representativa, o sílex. Os conjuntos líticos e suas inserções nas camadas estratigráficas indicam que a ocupação mais antiga foi há cerca de 4 mil anos AP. Está caracterizada por conjuntos líticos em quartzito, seguido de quartzo e sílex. As ocupações do Holoceno Recente estão representadas por expressiva quantidade de lascas de quartzito, associadas a poucos fragmentos cerâmicos, técnica de polimento aplicada a adorno, presença de cascas de frutos, fragmentos de ossos de animais e de carvões, além de estruturas de combustão e de instalação de estaca.

A análise a ser apresentada a seguir é composta de 240 lascas provenientes de fases de debitagem e de confecção de instrumentos, além de 15 instrumentos líticos lascados, provenientes do Corte 1 e Corte 2
(Unidade A), escavados por Schmitz et al. (1986), referentes às ocupações acerâmica. A partir destes objetos líticos, identificamos cadeias operatórias incompletas (momentos), advindas de esquemas técnicos específicos e representadas nas Figuras de 9, 10 e 12. Na medida do possível, procuramos relacionar, nesses esquemas, os conjuntos líticos do sítio GO-Cp-16 com aqueles provenientes do GOCp-17 (campos de seixos).

Para fins explicativos, informamos que as imagens esquemáticas apresentadas a seguir (Figuras de 9, 10 e 12) se referem a momentos da cadeia operatória: a "linha verde cheia" representa material presente no sítio; a "linha verde tracejada" representa os momentos hipotéticos das cadeias operatórias. Além disso, acima da linha verde, está o local da atividade técnica; abaixo dessa linha, o posicionamento das ações técnicas realizadas no processo de desenvolvimento da cadeia operatória; a "seta vermelha" indica o material transportado para 
o sítio GO-Cp-16 e o "círculo" indica quais materiais foram identificados e em qual localidade.

1) Fases de cadeias de operatórias de confecção de instrumentos de estrutura volumétrica não definida

Estão representadas por sete instrumentos em suportes predominantemente de quartzito. São lascas iniciais, corticais, sendo uma de entame, obtidas por percutor duro e gesto interno, e uma peça aproveitada de desplacamento de seixo. Apresenta dimensões que giram em torno de $7 \mathrm{~cm} \mathrm{x} 6 \mathrm{~cm}$ x 3 $\mathrm{cm}$. A modificação do suporte foi restrita à produção de gume transformativo, a partir de pequenos retoques obtidos por percussão direta, unidirecional e retoques bifaciais, curtos, para adelgaçamento do gume (plano de bico). Apresentam, em geral, uma única unidade técnica funcional transformativa. Em alguns casos, houve somente aproveitamento de gume naturalmente apto para desenvolver a ação técnica. É comum a presença de gumes visivelmente embotados, utilizados a partir de preensão de força. A técnica de lascamento dos retoques é caracterizada predominantemente pela utilização de percutor duro. Há lascas de retoques na coleção que poderiam estar relacionadas aos referidos instrumentos. É possível que a fase de debitagem, de produção dos suportes de tais instrumentos, não tenha ocorrido no próprio sítio (Figura 9).

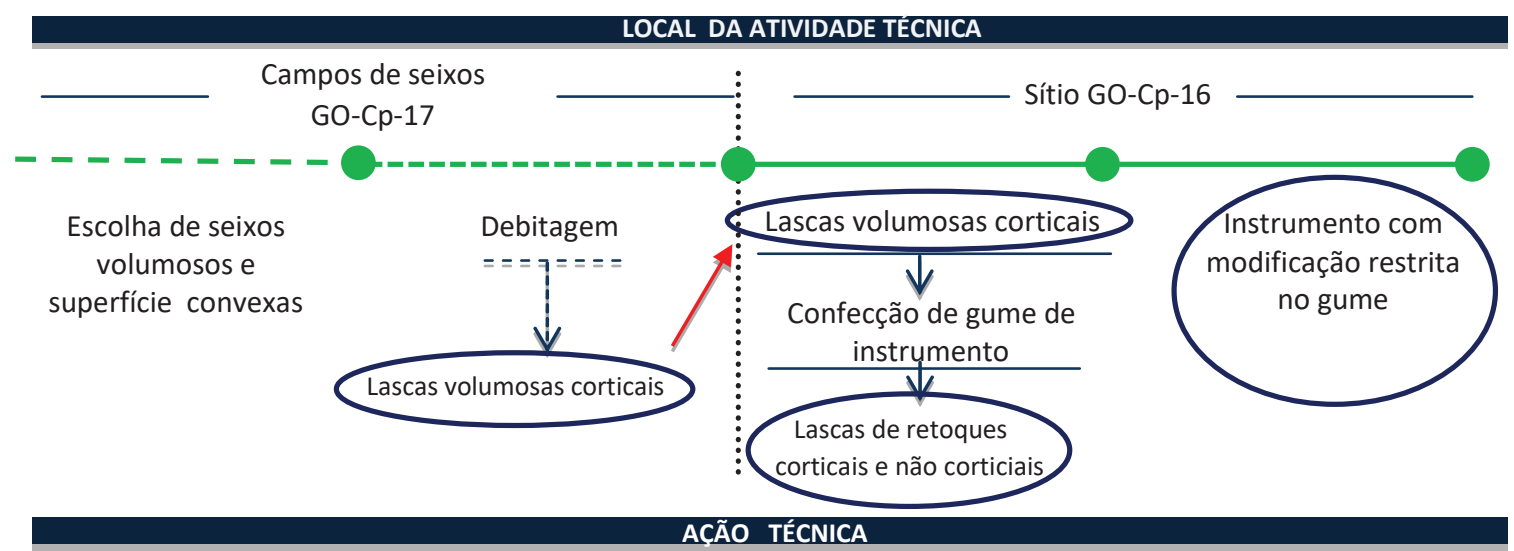

Figura 9 - Esquema dos momentos da cadeia operatória $\mathbf{n}^{\circ} \mathbf{1}$, de confecção de instrumentos de estrutura volumétrica não definida

Fonte: Elaborada pelos autores.

2) Fases de cadeias operatórias de confecção de instrumento de estrutura técnica compreendida por uma área abrupta (dorso) oposta à zona de instalação do gume transformativo

Estão representadas por três instrumentos de quartzito, sendo dois em seixo convexo e o outro sem presença de neocórtex. Os suportes são caracterizados por lascas volumosas, de talão e/ou dorsos espessos e aprumados. São objetos técnicos de estrutura assimétrica que guardam uma lógica técnica particular e predeterminada, advinda da debitagem: a área abrupta está em direção oposta à área de menor angulação, na qual ocorre o gume transformativo. Esta dupla está diretamente relacionada ao funcionamento do instrumento, estando as áreas mais avantajadas (dorsos) vinculadas à preensão de força. A relação percentual média entre a dimensão transversal da menor seção (no plano de corte e de bico) para a de maior seção (na lateral abrupta) é, em média, 39\%, ou seja, a menor dimensão corresponde a $39 \%$ da maior.

Os planos de corte e de bico (gume transformativo) foram confeccionados em momento específico de instalação das unidades tecnofuncionais transformativas. No que diz respeito à superfície de ataque, duas foram produzidas durante a fase de debitagem e uma aproveitada por desplacamento da matéria-prima. Quanto às laterais (dorsos) abruptas, duas são corticais e a outra está representada por talão espesso. A modificação do suporte é baixa, preservando indícios de sua estrutura original. As poucas sequências de retoques foram obtidas por 
percussão direta, unidirecional, utilizando percutor duro e gesto interno. As dimensões dos instrumentos giram em torno de $9 \mathrm{~cm}$ de comprimento, $8 \mathrm{~cm}$ largura e $5 \mathrm{~cm}$ de espessura. Há lascas de retoque no sítio, cujas características técnicas indicam que poderiam estar relacionadas à confecção de tais instrumentos (Figura 10 e 11).

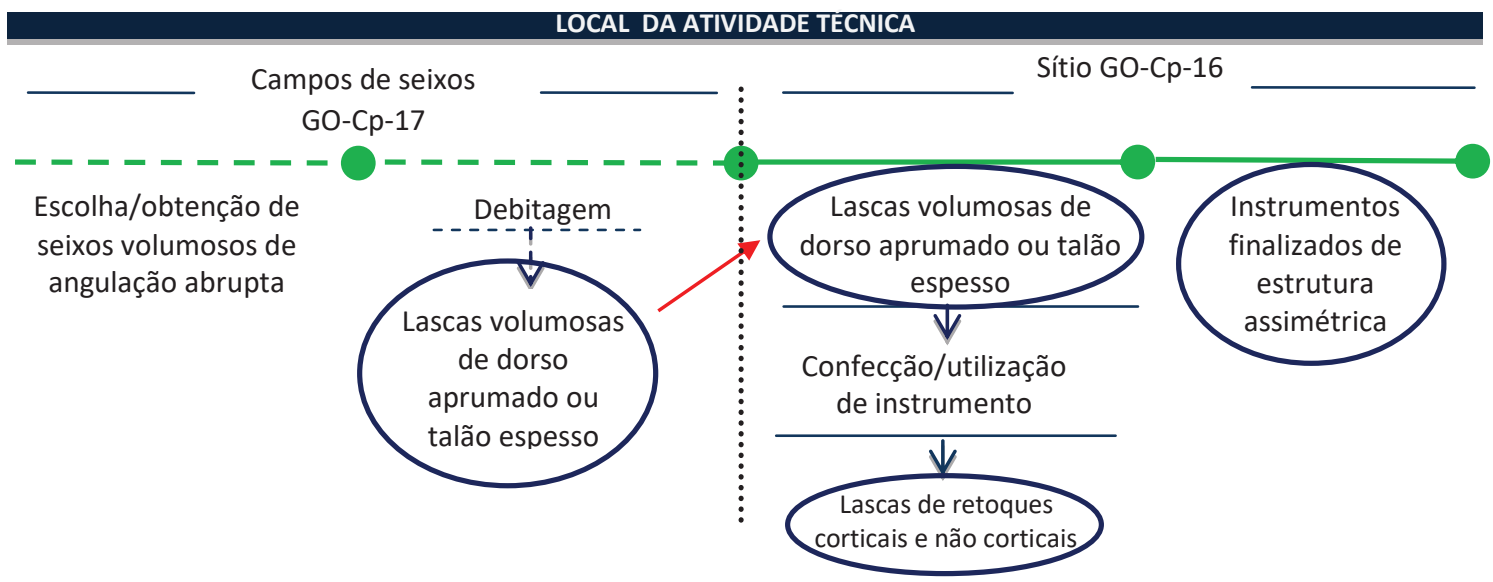

AÇAO TECNICA

Figura 10 - Esquema dos momentos da cadeia operatória $n^{\circ} 2$ referente a instrumentos assimétricos, compreendida por uma área abrupta (dorso) oposta à zona de instalação do gume transformativo Fonte: Elaborada pelos autores.

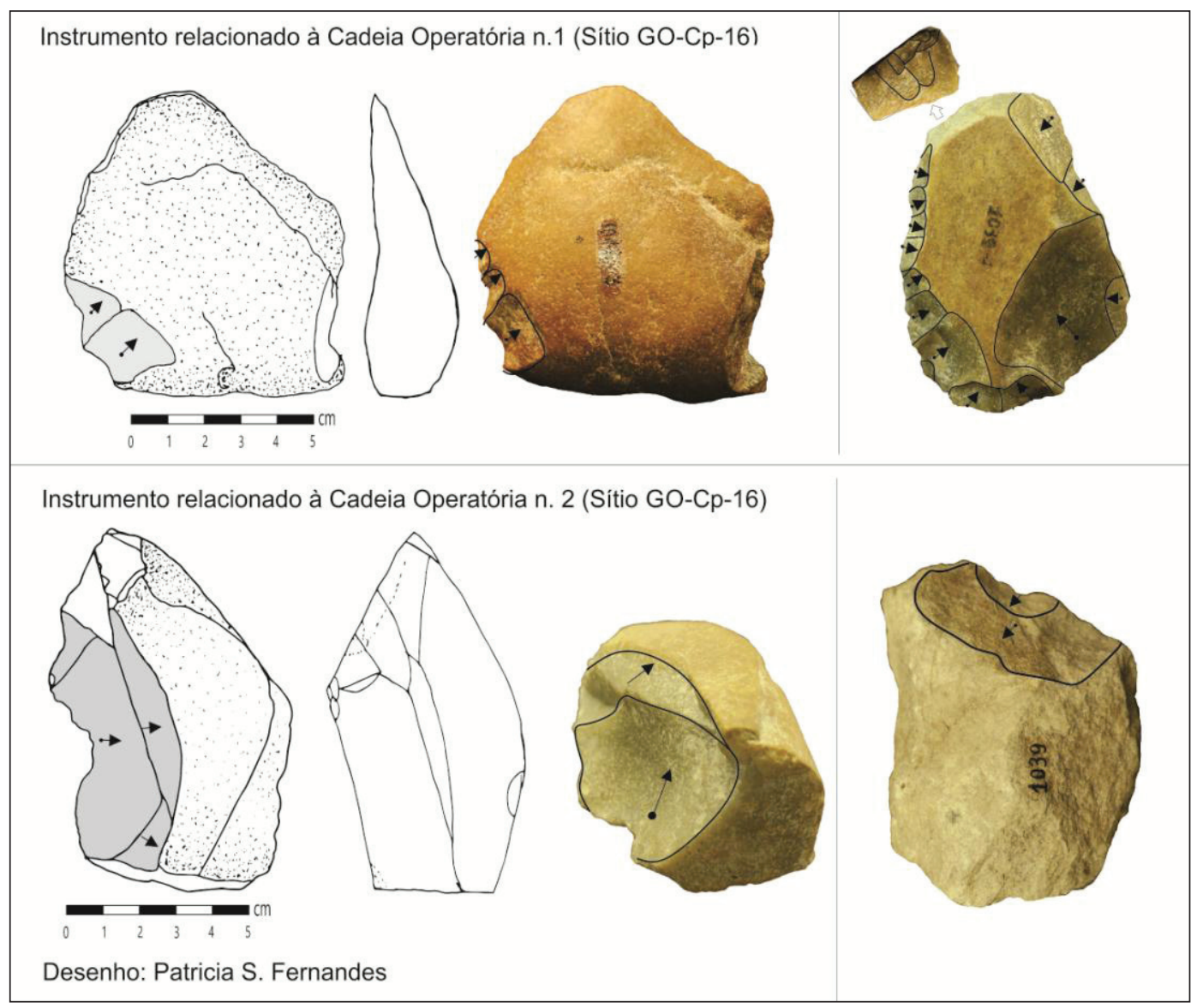

Figura 11 - Instrumentos relacionados às cadeias operatórias no 1 e no 2 Fonte: Elaborada pelos autores. 
3) Fases de cadeias operatórias provenientes de seleção de detritos de lascamento

São escolhas de suportes advindos de lascas de refugo de debitagem e/ou de fases de confecção de instrumentos (lascas de façonagem e retoque), os quais não teriam sido necessariamente predeterminados para esse fim. Como a intenção técnica não está na produção de lascas de façonagem ou de retoque, mas na confecção de um instrumento específico, consideramos que são suportes provenientes de intenção técnica secundária. Tais suportes totalizam dez peças, sendo somente uma em sílex e o restante em quartzito. As peças não seguem uma estrutura técnica determinada e suas dimensões máximas não ultrapassam $4 \mathrm{~cm}$ de comprimento, $3 \mathrm{~cm}$ de largura e $1,5 \mathrm{~cm}$ de espessura. A modificação da lasca-suporte para configuração do instrumento foi restrita à confecção de gumes implantados em áreas delimitadas (Figura 12).

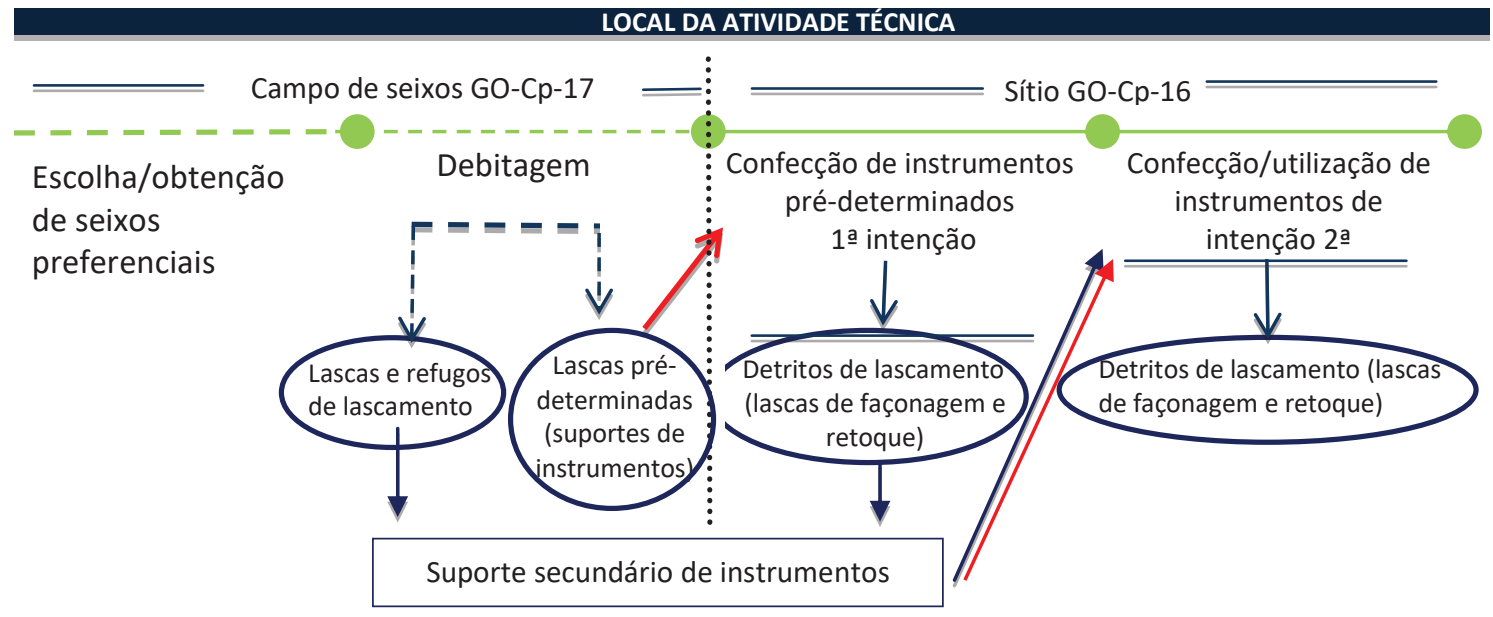

AÇAO TECNICA

Figura 12 - Esquema dos momentos da cadeia operatória $n^{\circ} 3$, referente a instrumentos em suporte provenientes de detritos de lascamento Fonte: Elaborada pelos autores.

É importante, ainda, assinalarmos a quantidade expressiva de fragmentos de lascas de retoques de quartzito presentes no sítio e a ocorrência de exemplares inteiros, bem definidos, de lascas de confecção de instrumento com características distintas daquelas identificadas para os instrumentos façonados unifacialmente. Essas lascas foram agrupadas em alguns conjuntos, entre os quais destacamos dois deles. O primeiro é composto por lascas muito finas, de talões quase imperceptíveis, bulbo muito difuso, produzindo superfícies superior e inferior planas, com vários negativos na face externa em sentidos diversos. Foram retiradas, certamente, por percutor macio e gesto periférico.

O outro conjunto é caracterizado por lascas de façonagem e retoque que apresentam talóes pouco espessos, perfil curvo, face externa com negativos dispostos em sentido paralelo ao eixo tecnológico de retirada da lasca. Nessas lascas, é recorrente a presença de um negativo ou córtex de dimensões pequenas, em posição distal, cuja direção é distinta do eixo tecnológico da lasca. Em sua face inferior, o lábio é proeminente, o ponto de impacto é difuso, o que indica a utilização de percutor macio e gesto periférico para a retirada das lascas. Tais características indicam produção de instrumentos de façonagem unifacial de estrutura técnica semelhante aos do sítio GO-Cp-17 e aos de Serranópolis, cujas cadeias operatórias de produção estão bem definidas para o Planalto Central brasileiro.

Sobre o sistema de debitagem presente no sítio GO-Cp-16, embora não tenham sido encontrados núcleos, as características técnicas das lascas de debitagem indicam uma diversidade de métodos de exploração. Tais evidências indicam que outras cadeias operatórias foram realizadas 
neste sítio e que os dados oriundos das escavações atuais, os quais se encontram em fase de análise e processamento, poderão fornecer pormenores da produção técnica que, associados com outras informações cronológicas e espaciais, nos auxiliarão a entender melhor as variabilidades técnicas dos instrumentos com façonagem unifacial (planoconvexo) de Palestina de Goiás.

\section{Discussão dos Dados}

Gostaríamos de apresentar discussões preliminares, refletindo inicialmente sobre o status dos sítios em "campos de seixos" no processo ocupacional da região, em especial o sítio GO-Cp-17. Primeiramente, é importante considerarmos que sua visibilidade atual pode estar relacionada à retirada da vegetação, às perdas de solos e aos processos erosivos de pequeno porte, como sulcos e calhas, frequentes na região. Já foi enfatizado pelas primeiras pesquisas que esses seriam locais estratégicos de disponibilidade de matéria-prima, no qual se transcorreram algumas ações técnicas, tais quais aprovisionamentos e confecções de instrumentos. Propomo-nos, contudo, a realizar um exercício de apreensão desses campos de seixos para além de sua categorização em termos unicamente estratégico-econômicos. Seguindo as proposições de Tuan (1983), entendemos estes espaços como lugares, ou seja, espaços apropriados e significados enquanto ambientes "vividos" (vécu) (BOËDA, 2013). Neles, relações eram estabelecidas e, assim, modificavam-se tanto componentes humanos quanto não humanos (LATOUR, 2012). Nesse sentido, propomo-nos a pensá-los enquanto lugares de materialização da subjetividade da "memória técnica", tendo em vista que as matériasprimas em seixos representam uma opção técnica particular, na qual os critérios de seleção são determinados por esquemas mentais construídos, modificados e renovados ao longo do tempo. É a isso que entendemos por "memória técnica" (BOËDA, 2013). Importante ainda considerar que, o "tempo" dedicado à escolha do seixo é primordial, representando, muitas vezes, a fase mais longa das cadeias operatórias de produção de instrumentos lascados. Essa seleção foi claramente reconhecida nos conjuntos líticos do sítio GO-Cp-17, quando constatamos a busca por seixos preferenciais, com características volumétricas particulares (superfícies aplainadas ou convexas), relacionadas à confecção de instrumentos específicos.

Também entendemos os campos de seixos como lugares de subjetivação da materialidade, traduzida no campo fenomenal contínuo e coerente que é a paisagem (INGOLD, 2011). Daí a importância de lançarmos foco sobre o caráter de processos em constante vir-a-ser que configura ambas as coisas materiais (como instrumentos líticos) e as coisas imateriais (como esquemas técnicos). Fazemos isso em detrimento de escolher tomar essas mesmas coisas como substâncias fixadas no tempo e espaço. Ao fazê-lo, trabalhamos com as condições epistêmicas que nos permitem aceder a descrições que não são diminuições do mundo vivido, mas, antes, interpretações que possuem o poder heurístico de captar nuances da alteridade humana pretérita (INGOLD, 2011; BOËDA, 2013).

Os sítios em campos de seixos, dentre eles o GO-Cp-17, assim como o sítio em abrigo, GO-Cp-16, são, em alguma medida, entendidos como lugares componentes de referências culturais, uma vez que ambos estão constituídos tanto pelas materialidades imbricadas nas técnicas como também por outras expressões culturais. Neles, há indícios macroscópicos de utilização intensa dos instrumentos, atestado pelos gumes desgastados e, muitas vezes, em estado de embotamento, lascas de refrescamentos de gumes de instrumentos, além da variabilidade de cadeias operatórias. Tais evidências, somadas às estruturas de combustão e às expressivas representações rupestres presentes no GO-Cp-16, levam-nos a entender que cada um dos sítios em estudo, em suas especificidades, são lugares onde foram engendradas atividades diversas. São lugares de referências tradicionais e, por isso, fizeram parte do projeto de humanidade vivido pelos primeiros habitantes da região de Palestina de Goiás.

Os objetos técnicos dos sítios GO-Cp-17 e GO-Cp-16 apresentam uma variabilidade de esquemas técnicos producionais e funcionais, estruturados em cadeias operatórias específicas. Expressam opções e soluções particulares de culturas 
que possuíam seus critérios próprios de "eficiência" e de "adequação", dados pela memória técnica herdada pelos indivíduos, mas renovada por meio do processo dinâmico das aprendizagens e dos saberes.

Entre estes dois sítios foram observados algumas conexões técnicas, dentre as quais a ampla utilização dos seixos, sendo plausível que os materiais sobre seixos do GO-Cp-16 sejam advindos dos sítios em "campos de seixos", que somam, ao todo, quatro na região. Outro elemento de conexão está na presença, em ambos os sítios, de confecção de instrumentos de estrutura assimétrica, compreendida por uma área abrupta (dorso) oposta à zona de instalação do gume transformativo, de menor angulação. Nesses instrumentos, é possível constatar que a zona de preensão foi prevista na escolha do seixo ou durante a fase de debitagem da lasca suporte. As variações da relação percentual entre as dimensões transversal da menor seção, na qual está instalado o plano de corte e de bico, para a de maior seção, onde se encontra a lateral (dorso) abrupta, é pequena (no sítio GOCp-17 é de 52\% e no GO-Cp-16 é de 39\%).

Outra afinidade técnica está na presença de instrumentos simétricos no sítio GO-Cp-17, façonados unifacialmente e de superfície externa com perfil convexo e face inferior aplainada, cuja estrutura técnica se assemelha aos de Serranópolis, embora sejam constatadas variabilidades regionais particulares nas peças de Palestina (VIANA; BORGES, 2014). Juntamente com eles, foram evidenciados, neste sítio, detritos característicos de sua produção (lascas de façonagem e de retoques), assim como lascas volumosas, que poderiam servir de suporte. Por outro lado, ainda que não tenham sido encontrados tais instrumentos no sítio em abrigo GO-Cp-16, foram identificados detritos indicativos de sua confecção, demonstrando fases diferenciadas de confecção e delineamento das bordas de peças façonadas unifacialmente. Há, portanto, indicações dos suportes terem sido transportados aos abrigos e lá terem sido confeccionados, sendo utilizados em locais que ainda não foram escavados ou estarem presentes em outros sítios.

No que concerne às conexões técnicas entre os sítios de Palestina e aqueles considerados na macrocontextualização cultural, momentaneamente podemos estabelecer algumas hipóteses. Todavia, como o nível de detalhamento em termos técnicos e tecnológicos presentes em cada uma das obras consultadas é muito variado, ainda não temos possibilidade de reconhecermos (com maior segurança) padrões confiáveis na composição dos conjuntos líticos (nível de análise tecnológica).

Pela análise macrorregional, observamos que a ocupação no período de transição do Pleistoceno para o Holoceno e Holoceno Inicial foi mais restrita na região. Entretanto, podemos observar nos sítios do Holoceno Médio, inclusive nos sítios de Palestina de Goiás, recorrências técnicas presentes em parte dos conjuntos líticos mais antigos. Entre eles, destacam-se a presença de instrumentos e produtos técnicos relacionados à produção de instrumentos façonados unifacialmente a partir de superfícies planas. Tais conjuntos são indicativos de convergências técnicas, conforme definição de Chavrier (2012), ou esquemas técnicos modificados e revigorados a partir de memórias técnicas, nos termos propostos por Boëda (2013).

O sítio GO-Ni-49 (Hidrolina/GO), inserido no contexto temporal do Holoceno Inicial, leva nossas considerações em outras direções. Se considerarmos a produção do volume do único exemplar de peça façonada unifacialmente evidenciada naquele sítio, observamos uma morfologia amendoada, com uma unidade técnica funcional transformativa na porção distal e de delineamento em ponta; confeccionada sobre matéria-prima de quartzito. Tais elementos se aproximam mais às peças identificadas nos sítios de Palestina de Goiás do que aquelas provenientes de Serranópolis. Além disso, o fato de mais de $95 \%$ do total do material ser sobre quartzo (leitoso, hialino e cristal de rocha) e a presença de instrumentos em pequenas lascas desta matéria-prima, faz-nos pensar que essa indústria destoa das características relativas ao Tecnocomplexo Itaparica. Por outrolado, levantamos, também, a hipótese de o sítio GO-Ni-49 possuir uma maior aproximação tecnológica com sítios líticos que apresentam marcada presença de objetos em quartzo e em dimensões pequenas, situações constatadas em Minas Gerais, Tocantins ou Piauí, ou seja, indicando, em termos macroespaciais, uma relação mais voltada para o Leste e Nordeste do Brasil. 
Em sítios do Holoceno Médio de algumas regiões citadas neste trabalho, como de Manso, de Serranópolis e de Palestina, são também recorrentes, entre outros, os instrumentos confeccionados em suportes de lascas espessas de estrutura assimétrica, caracterizadas por áreas abruptas (dorso) opostas à zona de instalação do gume transformativo, de menor angulação.

Também constatamos, em sítios deste período, que alguns abrigos sob rocha, como em Ferraz Egreja (Rondonópolis/MT), configuraramse, além de "habitação", como de produção de instrumentos líticos, visto que, conforme ressaltam os pesquisadores da área (VIALOU, 2006), todas as etapas de lascamento foram reconhecidas. Ressaltamos que, neste caso, as matérias-primas (na sua forma original ou pré-formas) eram levadas ao sítio. O mesmo ocorreu no sítio a céu aberto Estiva 2 (Chapada dos Guimarães/MT), no qual foi possível, ainda, discernir a variabilidade dos suportes das diferentes matérias-primas (seixos e blocos). Esse cenário é distinto do sudoeste de Goiás e do nordeste do Mato Grosso do Sul, pois estes relacionam-se respectivamente aos abrigos sob rocha GO-Ja-01 e AS12. E, nestes sítios, foram evidenciadas, segundo a bibliografia consultada, poucas lascas corticais, que poderiam testemunhar uma diferença marcante em relação aos sítios do Mato Grosso em termos de gestão da matéria-prima, uma vez que as fases de escolha e debitagem das lascas suporte estavam sendo realizadas fora dos sítios considerados "habitações". Outra possibilidade é de utilização do material proveniente do próprio abrigo (arenito silicificado).

Sobre sítios em afloramentos rochosos, temos o DF-PA-11 e o GO-Cp-17, que estão imbricados com a própria paisagem. No primeiro caso, ele se configura em situação de afloramentos de grandes blocos de quartzito, propícios ao lascamento, enquanto, no segundo, ocorrem os seixos de matérias-primas distintas, mas com predominância, também, de quartzito. Em ambos os sítios, há fortes indicativos, além dos processos de confecção da estrutura volumétrica dos instrumentos, da presença de retoques constantes (afiações) dos gumes transformativos e presença de gumes gastos pelos usos, o que sugere permanência e atividades para além das funcionalidades tradicionalmente atribuídas aos sítios "oficina".

Em geral, há poucas informações sobre os núcleos e os seus esquemas de exploração. No material que foi possível realizar análises comparativas, observamos que os núcleos do Holoceno Inicial e Médio foram explorados a expensas do sistema de debitagem tipo "C" (BOËDA, 2013), com exceção para a debitagem tipo “D” Manso, identificada uma peça no sítio GO-Cp-17 $7^{11}$. Todavia, considerando que a abordagem tecnofuncional é uma possibilidade que nos aporta meios de apreendermos as diferenciações entre esquemas de exploração de núcleos, encontramo-nos diante da necessidade de tentarmos identificar variabilidades regionais entre os núcleos tipo "C" e "D", evidenciados nos sítios dentro de nossa área de estudos. Essa é uma de nossas frentes de trabalho que ainda se encontra em desenvolvimento.

\section{Conclusão}

O complexo arqueológico de Palestina de Goiás vem, paulatinamente, demonstrando alto potencial investigativo para entendimento das ocupações pretéritas na região. Sua posição estratégica colabora para correlações ocupacionais mais amplas. A retomada da pesquisa na região teve início com a reanálise do material coletado entre 1979 e 1981 a partir de perspectivas teóricas e metodológicas centradas na tecnologia lítica, cujos resultados são parcialmente apresentados neste artigo. Esta ação foi essencial para sustentarmos os trabalhos posteriores, que ora estão em curso, e foi iniciada pela análise de material lítico de seis sítios líticos da bacia do Córrego do Ouro e dois do Torres do Bonito. Esse esforço resultou na produção de diversos trabalhos de conclusão de curso e um de mestrado (BORGES, 2009; FERNANDES, 2009; GUILHARDI, 2009, 2013; MORENO, 2010; ROSSI, 2015).

Paralelamente, iniciamos o trabalho com as pinturas rupestres pelo exame de cerca de 2.000 imagens fotográficas referentes aos 33 sítios com manifestações rupestres de Palestina de Goiás. O trabalho, embora em fase embrionária, 
apresenta resultados importantes acerca do estado de conservação das pinturas (SILVA et al., 2015) e dos diferentes momentos de produção dos grafismos da região (PECLAT, 2011). Ressaltamos, ainda, a pesquisa de mestrado de Cruvinel (2016) e de graduação de Lemos (2012), que se reportam às narrativas da comunidade de Palestina de Goiás sobre as manifestações rupestres dos sítios da região.

Sobre o material cerâmico, selecionamos o sítio GO-Cp-13, caracterizado por uma aldeia ceramista, para escavarmos áreas distintas daquelas executadas por Schmitz et al. (1986), com o intuito de obter amostras mais representativas de material arqueológico e melhor entendimento do processo de formação do sítio (LIMA, 2015). As escavações arqueológicas na área, restritas aos sítios GO-Cp-04, GO-Cp-16, GO-Cp-17 e GO-Cp-13, estão sendo realizadas de forma concomitante, mas não sistemática.

Estimamos que os resultados advindos das novas escavações e das análises dos materiais arqueológicos em curso venham não somente corroborar os dados obtidos até o momento, apresentados neste artigo, como também propiciar uma melhor compreensão da ocupação pretérita na região sudoeste de Goiás e da macrorregião contextual que ora delimitamos.

\section{Notas}

1 O Programa Arqueológico de Goiás (PAG) foi desenvolvido pela Universidade Católica de Goiás (UCG) e Universidade Vale do Rio dos Sinos, com a coordenação do Prof. Dr. Pedro Ignácio Schmitz e da equipe da UCG, foi iniciado na década de 1970, e suas últimas pesquisas ocorreram até a década de 1990, em Serranópolis.

2 Estas pesquisas são oriundas dos projetos "Análise do sistema tecnológico das indústrias líticas pré-históricas recuperadas pelo projeto Alto-Araguaia" (VIANA, 2006); "Patrimônio Arqueológico de Palestina de Goiás" (VIANA, 2011) e "Pré-História de Palestina de Goiás" (VIANA, 2015), foram financiados pelo CNPq e FAPEG.

3 A escolha por um raio de $400 \mathrm{~km}$ se baseou na delimitação de uma área que permitisse uma abertura diacrônica e sincrônica, em termos culturais, para problematizar as ocupações dos sítios de Palestina de Goiás.

4 Quando os sítios não apresentavam datação, seguimos considerações dos autores acerca das relações cronológicas sustentadas pelas datações relativas.
5 Por gênese, entende-se que os objetos técnicos estão inscritos em uma história da materialidade, são derivados de evoluções e serão, eles mesmos, a origem de outras invenções (SIMONDON, 1969; DEFORGE, 1985, CHEVRIER, 2012; BOËDA, 2013).

6 "Ao lado da convergência biológica, existe uma convergência técnica a qual oferece, desde os inícios da Etnologia, uma parte da refutação das teorias de contato" (LEROI-GOURHAN, 1945, p. 338, tradução livre).

7 Segundo Souza (2015), a relação deste sítio às ocupações antigas baseia-se nas características tecnológicas da cultura material lítica.

8 Com base em Mansur (1986): Cortar: inserção de um gume produzido ou natural na substância a ser trabalhada, exercer um movimento paralelo ao eixo do gume, geralmente bidirecional. Essa ação se aplica geralmente aos materiais moles. Raspar: desbastamento de uma superfície com o gume segurado perpendicularmente à direção de utilização. Oângulo de trabalhoésempre superior a $45^{\circ}$ e constantemente próximo de $90^{\circ}$. Furar: inserção de uma ponta por rotação contínua unidirecional, segurada perpendicularmente à superfície a ser trabalhada.

9 Encontra-se em curso artigo científico sobre a produção desta cadeia operatória.

10 As descrições das camadas foram realizadas em campo utilizando 1) análise granulométrica, proposta por Shepard (1945), sensibilidade ao tato (areia=aspereza; silte $=$ sedoso; argila $=$ plástica e pegajosa); 2) coloração, a partir do código do "Code des Couleurs des sols. NoticeSur” (CAILLEUX, [s. d.]); 3) arredondamento e esfericidade dos minerais (SUGUIO, 1980) e 4) análise mineralógica. Utilizou-se, ainda, lupa manual, ácido clorídrico e imã.

11 Análises em andamento constatam a presença de debitagem do tipo "D" em alguns sítios do Holoceno Médio de Serranópolis.

\section{Referências}

AGÊNCIA NACIONAL DAS ÁGUAS. 2016. Disponível em: <https://www2.ana.gov.br >. Acesso em: 10 abr. 2016.

ALMEIDA, F. F. M. de; BRITO-NEVES, B. B. de; CARNEIRO, C. D. R. The origin and evolution of the South American Plataform. Earth-Sci Rev., v. 50, n. 1/2, p. 77-111, 2000.

ALVES, M. A. A Arqueologia no extremo Oeste de Minas Gerais. Revista Espinhaço, v. 2, n. 2, p. 96117, 2013. 
BARBOSA, A. S.; SCHMITZ, P. I.; MIRANDA, A. F. Um sítio paleoíndio no meio norte de Goiás (novas contribuições ao estudo do Paleoíndio em Goiás). Anuário de Divulgação Científica. Goiânia: UCG/ IGPA, 1976/1977.

BOËDA, E. Techno-logique et technologie. Une Paléo-histoiredesobjetstranchants. Paris: Archéoéditions, 2013.

BORGES, C. T. Oficina lítica de superfície GOCP-17 (Palestina de Goiás - GO): atual análise, novas propostas, possíveis interpretações. 2009. 120 f. Trabalho de Conclusão de Curso (Graduação em Arqueologia) - Pontifícia Universidade Católica de Goiás (IGPA), Goiânia, 2009.

CAILlEUX, A. Code des couleurs des sols. NoticeSur Le. Paris: Editions Boubeé, [s. d.].

CHEVRIER, B. Ni espace ni temps en préhistoire ancienne: "Out of Africa" ou le paradigme de la fleche. M@ppemonde, Avignon, v. 106, n. 2, p. 1-18, 2012.

CRUVINEL, F. O olhar do outro: a arte rupestre de Palestina de Goiás e a comunidade local. 2016. 153 f. Dissertação (Mestrado em Arqueologia) - Programa de Pós-Graduação em Arqueologia, Pontifícia Universidade Católica de Goiás, Goiânia, 2016.

DEFORGE, Y. Technologie et génétique de l'objet industriel. Paris: Ed. Maloine, 1985. (Collection université de Compiègne).

FERNANDES, P. F. Caçador-Coletor: uma (re) análise do material lítico dos sítios arqueológicos da região de Palestina de Goiás/GO. 2009. 102 f. Trabalho de Conclusão de Curso (Graduação em Arqueologia) - Pontifícia Universidade Católica de Goiás (IGPA), Goiânia, 2009.

FOGAÇA, E.; LOURDEAU, A. Uma abordagem tecnofuncional e evolutiva dos instrumentos planos-convexos (lesmas) da transição Pleistoceno/ Holoceno no Brasil Central. Fumdhamentos, São Raimundo Nonato, v. 7, p. 261-347, 2008.

GOOGLE EARTH. Mapas. Disponível em: <https:// www.google.com/earth>. Acesso em: 1 abr. 2016.
GUILHARDI, P. P. Sítios lito-cerâmicos de Palestina de Goiás: uma abordagem da tecnologia lítica. 2009. 130 f. Trabalho de Conclusão de Curso (Graduação em Arqueologia) - Pontifícia Universidade Católica de Goiás (IGPA), Goiânia, 2009.

Flint acquisition in GO-CP-16 archaeological site: a flintraw material characterization study. 2013. 184 f. Dissertação (Mestrado em Arqueologia) - Muséum National d'Histoire Naturelle, Paris, 2013.

INGOLD, T. Anthropology is not ethnography. In: Being Alive: essays on movement, knowledge and description. London: Routledge, 2011. p. 229-265.

LATOUR, B. Reagregando o social: uma introdução à teoria do Ator-Rede. Salvador/Bauru: EDUFBAEDUSC, 2012.

LEMONNIER, P. Introduction. In: (Org.). Technological choices - transformation in material culture since the Neolitic. London: Routledge, 2002. p. 1-35.

LEMOS, M. M. Patrimônio arqueológico da região sudoeste de Goiás: ações de educação patrimonial. 2012. 73 f. Trabalho de Conclusão de Curso (Curso de Arqueologia) - Pontifícia Universidade Católica de Goiás (IGPA), Goiânia, 2012.

LEROI-GOURHAN, A. Milieu et techniques. Paris: Albin Michel, 1945.

LIMA, F. R. Da interpretação dos vestígios arqueológicos cerâmicos ao entendimento das formas de interação com a paisagem: um estudo de caso do sítio GO-Cp-13. Palestina de Goiás. 2015. 61 f. Trabalho de Conclusão de Curso (Graduação em Arqueologia) - Pontifícia Universidade Católica de Goiás (IGPA), Goiânia, 2015.

LOURDEAU, A. Tecnologia lítica e primeiros povoamentos no Sudeste do Estado de Goiás. In: MOURA, M. C. O. de; VIANA, S. A. (Org.). A transversalidade do conhecimento científico: uma experiência de 40 anos em pesquisa. Goiânia: Editora 
da Pontifícia Universidade Católica de Goiás, 2013. p. 73-96.

Le technocomplexe Itaparica. 2010. $476 \mathrm{f}$. These (Doctorat em Archéologie) - Université Paris Ouest Nanterre La Défense, Paris, 2010.

MANSUR, M. E. Microscopie du matériel lithique préhistorique. Traces d'utilisation, altérations Naturelles, accidentelles et technologiques. Paris: Éditions du Centre National de la Recherche Scientifique, 1986.

MARTINS, G.; KASHIMOTO, E. 12.000 anos: Arqueologia do povoamento humano no nordeste de Mato Grosso do Sul. Campo Grande: Life Ed., 2012.

MELLO, P. J. C. Análise dos sistemas de Produção e da Variabilidade Tecnofuncional de Instrumentos

Retocados: as indústrias líticas a céu aberto do vale do rio Manso/MT. 2005. 303 f. Tese (Doutorado em História) - Programa de Pós-Graduação em História, Pontifícia Universidade Católica do Rio Grande do Sul, Porto Alegre, 2005.

MELLO, P. J. C.; VIANA, S. A. Breve histórico da arqueologia de Goiás. In: Moura (Org.) Índios de Goiás: uma perspectiva histórico-cultural. Goiânia: Eds. UCG. Kelps, Vieira. 2006.

MILANI, E. J.; MELO, J. H. G. de; SOUZA, P. A. de; FERNANDES, L. A.; FRANÇA, A. B. Bacia do Paraná. Bol. Geoc. Petrobrás, Rio de Janeiro, v. 15, n. 2, p. 265-287, 2007.

MORENO, J. C. Mente, corpo e cultura em pedras: a cognição humana na tecnologia pré-histórica. 2010. 237 f. Trabalho de Conclusão de Curso (Graduação em Arqueologia) - Pontifícia Universidade Católica de Goiás, Goiânia, 2010.

PEREIRA, E. Estratigrafia da formação Vila Maria (Landoveriano), na sub-bacia de Alto Garças (Bacia do Paraná), Brasil. An. Acad. Bras. Cienc., Rio de Janeiro, v. 70, p. 501-525, 1998.

.; CARNEIRO, C. D. R.; BERGAMASCHI, S.; ALMEIDA, F. F. M. Evolução das sinéclises paleozoicas: Províncias Solimões, Amazonas, Parnaíba e Paraná. In: HASUI, Y.; CARNEIRO, C. D. R.; ALMEIDA, F. F. M.; BARTORELLI, A. (Org.). Geologia do Brasil. São Paulo: Beca, 2012. p. 374394.

PECLAT, T. A. C. Sobrepondo conceitos: reflexões sobre os momentos de produção dos grafismos rupestres do sítio arqueológico GO-Cp.-09. 2011. 103 f. Trabalho de Conclusão de Curso (Graduação em Arqueologia) - Pontifícia Universidade Católica de Goiás, Goiânia, 2011.

RAMOS, M. P. de M.; VIANA, S. A. Revisitando o Arcaico: hiatos ocupacionais ou hiatos documentais? Comunicação oral apresentada na Semana dos Povos Indígenas e V Jornada de Arqueologia no Cerrado, Pontifícia Universidade Católica de Goiás, 2016.

ROSSI, M. A. Tecnologialítica: análise tecnofuncional do material lítico do sítio arqueológico GO-CP.34 Palestina de Goiás/GO. 2015. 139 f. Trabalho de Conclusão de Curso (Graduação em Arqueologia) - Pontifícia Universidade Católica de Goiás, Goiânia, 2015.

RIBEIRO, J. F.; WALTER, B. M. T. As principais fitofisionomias do bioma Cerrado. In: SANO, S. M.; ALMEIDA, S. P.; RIBEIRO, J. F. (Ed.). Cerrado: ecologia e flora. Brasília: Embrapa Cerrados, 2008. p. 151-212.

RUBIN, J. C. R.; SILVA, R. T.; CORREA, D. S.; SILVA, S. M.; BARBOSA, J. B. Nueva perspectiva del abrigo del sitio arqueológico GO-Cp-04, Goiás, Brasil. In: CONCEPCIÓN J. J. (Ed.). VII Simpósio Internacional: El Hombre Temprano em America. Ciudad de Mexico: UNAM, 2016. No prelo.

SCHMITZ P. I.; RIBEIRO, M. B.; BARBOSA, A. S.; BARBOSA, M. O.; MIRANDA A. F. Arqueologia nos cerrados do Brasil Central: Caiapônia. São Leopoldo: IAP/UNISINOS, 1986. .; ROSA, A. O.; BITENCOURT, A. L. V. Arqueologia nos cerrados do Brasil Central. Serranópolis III. Pesquisas, Antropologia, São Leopoldo, n. 60, p. 286, 2004. 
SHEPARD, F. P. Nomenclature base do sand-silt-clay ratios. Journal Sedimentary Petrology, Tulsa, v. 24, p. 151-158, 1954.

SILVA, A. L. M.; SILVA, B. D.; PEREIRA, L. G.; LINO, M. C. Relatório de atividades: revisão dos arquivos fotográficos dos sítios arqueológicos do projeto Alto Araguaia. Pontifícia Universidade Católica de Goiás, Goiânia, 2015.

SIMONDON, G. Du mode d'existence des objets techniques: analyse et raisons. Paris: AubierMontaigne, 1969.

SOUZA, E. Sistema de debitagem em sítio lítico a céu aberto (DF-PA-11) - Ceilandia - DF. 2015. 133 f. Trabalho de Conclusão de Curso (Graduação em Arqueologia) - Pontifícia Universidade Católica de Goiás, Goiânia, 2015.

SUGUIO, K. Rochas sedimentares: propriedades, gênese, importância econômica. São Paulo: Edgard Blucher, 1980.

TUAN, Y. Espaço e lugar: a perspectiva da experiência. São Paulo: Difel, 1983.

VIALOU, Á. V. (Org.). Pré-história do Mato Grosso - Vol. 2: Cidade de Pedra. São Paulo: Udusp, 2006.

.; FIGUTI, L. (Org.). Cidade de Pedra: passado e presente. 1. ed. São Paulo: Maluhy \& Co., 2013.

VIANA, S. A. Variabilidade tecnológica do sistema de debitagem e de confecção dos instrumentos lascados de sítios lito-cerâmicos da região do Rio Manso, MT. 2005. 355 f. Tese (Doutorado em
História) - Programa de Pós-Graduação em História, Pontifícia Universidade Católica do Rio Grande do Sul, Porto Alegre, 2005.

Análise do sistema tecnológico das indústrias líticas pré-históricas recuperadas pelo projeto Alto-Araguaia. Goiânia: IGPA/PUC Goiás, 2006.

Patrimônio arqueológico do sudoeste de Goiás. Goiânia: IGPA/PUC Goiás, 2011.

Pré-história de Palestina de Goiás. Goiânia: IGPA/PUC-Goiás, 2015.

; BORGES, C. T. Compreendendo ferramentas líticas a partir das persistências e das variabilidades técnicas - estudo de caso dos sítios GO-CP-17 e MT-SL-31/Região Centro Oeste do Brasil. In: LOURDEAU, A.; GLUCHY, F. M. (Org.). Peuplement de l'Amériquedusud: l'apport de la techronologie lithique. Paris: Archéo-éditions, 2014. p. 3-17.

.; LOURDEAU, A.; HOELTZ, S.; GLUCY, M. F. Esquemas operatórios de produção Lítica na pré-história do Brasil. In: LOURDEAU, A.; VIANA, S.; RODET, J. (Org.). Indústrias líticas na América do Sul: abordagens teóricas e metodológicas. Recife: Editora UFPE, 2014. p. 143-170. (Série Estudos Contemporâneos na Arqueologia).

VIANA, S. A.; RAMOS, M. P.; LOURDEAU, A.; ROSSI, M. A.; BOËDA, E. Os sítios líticos a céu aberto da região arqueológica de Caiapônia. Livro de Resumos do XVIII Congresso da Sociedade de Arqueologia Brasileira. Goiânia: IGPA/PUC Goiás, 2015. 